Deliberative Engagement within the World Trade Organization: A Functional Substitute for Authoritative Interpretations

Creamer, Cosette; Godzimirska, Zuzanna

Published in:

New York University Journal of International Law \& Politics

Publication date:

2016

Document version

Publisher's PDF, also known as Version of record

Citation for published version (APA):

Creamer, C., \& Godzimirska, Z. (2016). Deliberative Engagement within the World Trade Organization: A

Functional Substitute for Authoritative Interpretations. New York University Journal of International Law \& Politics , 48(2), 413-462. 


\section{HEINONLINE}

Citation: 48 N.Y.U. J. Int'I L. \& Pol. 413 2015-2016

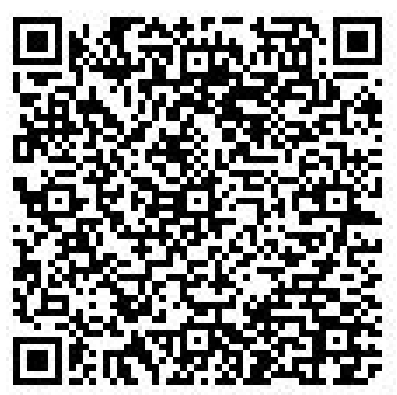

Content downloaded/printed from HeinOnline (http://heinonline.org) Tue Jul 12 03:50:10 2016

-- Your use of this HeinOnline PDF indicates your acceptance of HeinOnline's Terms and Conditions of the license agreement available at http://heinonline.org/HOL/License

-- The search text of this PDF is generated from uncorrected OCR text.

-- To obtain permission to use this article beyond the scope of your HeinOnline license, please use:

https://www.copyright.com/ccc/basicSearch.do? \&operation $=$ go\&search $\mathrm{Type}=0$ \&lastSearch $=$ simple\&all $=$ on\&titleOrStd $N o=0028-7873$ 


\title{
DELIBERATIVE ENGAGEMENT WITHIN THE WORLD TRADE ORGANIZATION: A FUNCTIONAL SUBSTITUTE FOR AUTHORITATIVE INTERPRETATIONS
}

\author{
Cosette D. Greamer \& ZuZanna Godzimirska*
}

The transition from the General Agreement on Tariffs and Trade (GATT) dispute settlement proceedings to the Dispute Settlement Mechanism (DSM) of the World Trade Organization (WTO) represented a notable instance of judicialization within international economic governance. Since it began ruling on trade conflicts in 1995, the DSM has enjoyed significantly greater independence from direct government control than its GATT predecessors. It has also exercised a greater degree of interpretive autonomy than initially intended by WTO member governments ("Members"). This development largely stems from deadlock among Members and norms of consensus decision-making, which have thwarted use of one of the primary means of legislative response within the WTO: authoritative interpretations. Authoritative interpretations theoretically provide the WTO's political bodies-the membership as a whole-with an opportunity to respond to interpretations or practices of its adjudicative bodies that are perceived to be at odds with governments' intention, will, or preferences. Yet the current ineffective nature of authoritative interpretations creates a predicament not only for the WTO's political organs. It also deprives the DSM of constructive normative guidance from its primary constituents: its Members. This Article proposes a functional substitute for the mechanism of authoritative interpretations, namely increased input from Members (in the form of statements within meetings of the WTO Dispute Settlement Body) prior to adoption of the dispute settlement rulings. We argue that such an increase would better enable the DSM to consider the interpretive preferences of the WTO membership as a whole, thus enabling it to better fulfill its fiduciary duties and its responsibility of deliberative engagement with Members in particular. This Article

* Cosette D. Creamer is a Visiting Assistant Professor at Boston University School of Law and a Ph.D. Candidate in the Department of Government, Harvard University. In Fall 2016, she will start as an Assistant Professor and Benjamin E. Lippincott Chair in Political Economy at the University of Minnesota. She holds a J.D. from Harvard Law School. Zuzanna Godzimirska holds a Master of Laws from the University of Oslo and is a Ph.D. Fellow at iCourts, Centre of Excellence for International Courts, Faculty of Law, University of Copenhagen. The authors thank Karen Alter, Laura Nielsen, Mark $\mathrm{Wu}$, and a number of WTO Member delegates in their personal capacity for helpful comments. This research is funded by the Danish National Research Foundation Grant No. DNRF105 and conducted under the auspices of iCourts, the Danish National Research Foundation's Centre of Excellence for International Courts. 
specifies how the proposal would work in practice and addresses potential limitations and obstacles to its implementation.

I. InTRODUCTION ....................... 414

II. Legislative Response Within the WTO ....... 424

III. Expression of Views Prior to Report Adoption: Current Practices............... 433

A. Procedure and Purpose of Statements on Dispute Reports........................... 434

B. Overview of Report Statement Practices......... 436

C. Trends in the Use of Report Statements ........ 438

D. Content of Report Statements ............... 442

E. Current Use of Report Statements to Communicate with the DSM........................ 446

IV. Deliberative Engagement Through Expression OF VIEWS ............................ 449

A. The Duty of Deliberative Engagement in the WTO ................................. 449

B. Improving on Current Practices ............ 452

C. Potential Limitations and Obstacles ........... 453

V. Conclusion ......................... 459

\section{INTRODUCTION}

Over the past century, governments have increasingly granted international judicial and quasi-judicial bodies the authority to interpret legal agreements, resolve disputes, or enforce international rules. This trend has historically been and continues to be a puzzling one for international legal scholars and government officials trained to guard zealously the boundaries of state sovereignty. Many assume that states can exercise sufficient control over these tribunals or exit the regime if membership costs begin to outweigh benefits. ${ }^{1} \mathrm{Al}-$ though delegating authority to an international body is controversial and raises a number of concerns about sovereignty, legitimacy, and accountability, ${ }^{2}$ international courts also clarify

1. See, e.g., Eric A. Posner \& John C. Yoo, Judicial Independence in International Tribunals, 93 CAL. L. Rev. 1 (2005) (arguing that international tribunals cannot, and should not, be completely independent and should act in line with the interests of the states that created them).

2. See, e.g., Curtis A. Bradley, International Delegations, The Structural Constitution, and Non-Self Execution, 55 STANFORD L. REv. 1557 (2003) (assessing some of the constitutional implications of United States' delegations of au- 
obligations, help states overcome cooperation problems, and contribute more generally to the development of an international legal system. ${ }^{3}$ Perhaps for this reason, states continue to create formally independent tribunals, particularly in the area of international economic law.

In the context of international trade, scholars and practitioners have cautioned about a growing institutional imbalance within the World Trade Organization (WTO) between its political and quasi-judicial bodies. ${ }^{4}$ The Organization's adjudicative bodies consist of dispute settlement panels and the Appellate Body, together referred to as the Dispute Settlement Mechanism (DSM) of the Organization. ${ }^{5}$ The rulings of the

thority to international institutions, including international courts); Thomas M. Franck, Can the United States Delegate Aspects of Sovereignty to International Regimes?, in Delegating State Powers: The Effect of Treaty Regimes on Democracy and Sovereignty 1-2 (Thomas M. Franck, ed., 2000) (describing the "intense criticism" directed at the lack of democratic accountability in many international regimes); Oona A. Hathaway, International Delegation and State Sovereignty, 71 L. \& ConTEMP. ProBs. 115 (2008) (addressing concerns about state sovereignty when delegating authority to international institutions); Julian G. Ku, International Delegation and the New World Court Order, 81 WASH. L. RFV. I (2006) (presenting a comprehensive constitutional critique of U.S. domestic courts' enforcement of international tribunals' decisions); David A. Lake, Delegating Divisible Sovereignty: Sweeping a Conceptual Minefield, 2 REV. INT'L ORG. 219 (2007) (reviewing the sources of controversy and criticism over delegating authority to international organizations); Armin von Bodgandy, The Democratic Legitimacy of International Courts: A Conceptual Framework, 14 THEORETICAL INQ. L. 361 (2013) (providing a conceptual framework to address the issue of democracy and democratic legitimacy of international courts).

3. See, e.g., Armin von Bogdandy and Ingo Venzke, In Whose Name? An Investigation of International Courts' Public Authority and Its Democratic Justification, 23 EUR. J. INT'L L. 7, 8 (2012) (noting that international courts are "part of strategies that pursue shared aims, seek to overcome obstacles of cooperation, and try to mend failures of collective action").

4. See, e.g., Claus-Dieter Ehlermann \& Lothar Ehring, The Authoritative Interpretation Under Article XI:2 of the Agreement Establishing the World Trade Organization: Current Law, Practice and Possible Improvements, 8 J. INT'L ECON. L. 803,815 (2005).

5. In this Article we refer to the WTO dispute settlement panels and the Appellate Body as comprising together "the Dispute Settlement Mechanism" (DSM), "the adjudicative bodies," or "the quasi-judicial bodies" of the WTO. Panels consist of experts selected on an ad hoc basis to resolve disputes between WTO Members, while the Appellate Body is a permanent body responsible for reviewing the legal aspects of panel reports if and when those are appealed. Understanding on Rules and Procedures Governing the Settle- 
DSM are subject to adoption by the Dispute Settlement Body (DSB), a political body comprised of all Member representatives. The norm that all decisions adopted within the political bodies of the WTO-including the DSB-should be reached by consensus has led to a political decision-making stalemate. At the same time, the scope of the adjudicative bodies' exercise of authority has grown through its rulings. Despite increased concern over this institutional imbalance, WTO member governments ("Members") have made few noticeable efforts to tackle the challenges that ineffective mechanisms of political response create for the Membership in the face of the adjudicative bodies' increased autonomy. ${ }^{6}$ This Article proposes a functional substitute for existing modes of legislative response within the WTO, which should prove useful to both WTO Members and its adjudicative bodies.

During the Uruguay Round negotiations establishing the WTO, states parties agreed to create an overarching institutional framework to transform the decentralized General Agreement on Tariffs and Trade (GATT) system into a formal international organization. While negotiating states did voice sovereignty concerns about the implications of moving from the GATT to a formal organizational model, ultimately these concerns did not prevail. ${ }^{7}$ Under the WTO's more institutionalized framework for negotiations and decision-making, Mem-

ment of Disputes arts. 16-17, Apr. 15, 1994, Marrakesh Agreement Establishing the World Trade Organization, Annex 2, 1869 U.N.T.S. 401 [hereinafter DSU].

6. On the tensions between the political and adjudicative bodies of the WTO, see generally Claus-Dieter Ehlermann, Tensions Between the Dispute Settlement Process and the Diplomatic and Treaty-Making Activities of the WTO, 1 WORLD Trade Rev. 301 (2002) (arguing that the political decision-making process, compared to the strong dispute settlement process, appears weak and inefficient because it is de facto governed by the principle of consensus, creating a troubling imbalance within the Organization); John H. Jackson, The WTO 'Constitution' and Proposed Reforms: Seven 'Mantras' Revisited, $4 \mathrm{~J}$. INT'L ECON. L. 67, 73 (2001) (suggesting that if the decision- and rule-making processes are ineffective, Members might be inclined to resort to dispute settlement, leading the dispute settlement system to "take on issues that it ought not to"); Armin von Bogdandy, Law and Politics in the WTO-Strategies to Cope with a Deficient Relationship, 5 Max Planck Y.B. OF U.N. L. 609, 614 625 (2001).

7. See Ernst H. Preeg, Traders in a Brave New World: The Uruguay Round and the Future of the International Trading System 122-26, 20710 (providing an overview of Uruguay Round negotiations over the creation 
bers serve various functions on councils and committees, which constitute the WTO's political-and in some sense legislative--bodies. ${ }^{8}$ In fact, the WTO describes itself as "memberdriven" and both Member representatives and WTO officials repeat this phrase as a self-affirming mantra. ${ }^{9}$ Members thus view themselves as the primary constituents of the Organization as a whole and of its dispute settlement system in particular.

The transition from the GATT dispute settlement proceedings to the WTO's Dispute Settlement Mechanism (DSM) represented a notable instance of judicialization within international economic governance, in that it significantly increased the independence of the DSM from direct Member control. ${ }^{10}$ Negotiating states intended to maintain a political check on the WTO's newly created adjudicative bodies but in practice the DSM enjoys interpretive autonomy. The General Council sitting as the Dispute Settlement Body (DSB), a political organ consisting of WTO Member representatives, formally adopts dispute reports and issues implementation recommendations under a reverse consensus rule, ${ }^{11}$ but the primary re-

of an organizational form and noting the concerns voiced by the United States delegate in particular).

8. Disagreement persists over whether and how to analogize domestic legal structures to international organizations, but a fair bit of existing scholarship presumes that the political bodies of the WTO perform what can be characterized as a legislative function. See, e.g., Bogdandy, supra note 6, at 614 (pointing out that the WTO Agreement establishes a separation of powers within the WTO system between the legislative, executive, and adjudicative branches); Mary E. Footer, An Institutional and Normative Analysis of the World Trade Organization 26 (2006); Gregory Schaffer \& Joel Trachtman, Interpretation and Institutional Choice at the WTO, 1 OÑaTı SOCIOLegal Series 1 (2011).

9. Footer, supra note 8, at 28; WTO Info. \& External Relations Div., Understanding the WTO 101 (2011).

10. See, e.g., Ernst-Ulrich Petersmann, The Dispute Settlement System of the World Trade Organization and the Evolution of the GATT Dispute Settlement System Since 1948, 31 Common Mkт. L. Riv. 1157 at 1215 (1994) (referring, inter alia, to the fact that panel and Appellate Body reports are adopted unless disapproved by consensus as indicative of increased independence of the WTO DSM compared to dispute settlement proceedings under the GATT).

11. The primary political body of the WTO-the General Council (GC) -handles the day-to-day work of the organization, including administration of the DSM when sitting as the DSB. Marrakesh Agreement Establishing the World Trade Organization, art. IV, Apr. 15, 1994, 1867 U.N.T.S. 154 [hereinafter Marrakesh Agreement]. The general rule within the DSB is to 
sponsibility for clarifying provisions within the WTO covered agreements rests with the adjudicative bodies of the Organization, i.e. dispute panels and the Appellate Body (AB). ${ }^{12}$ Because nearly every decision taken by the WTO's political bodies requires consensus of all Members, the ability of governments, individually or collectively, to provide formal guidance to or influence over the DSM through established treaty mechanisms has become a near impossibility. ${ }^{13}$ This poses a problem for Members, but also represents a significant challenge for the DSM, which depends on feedback from the membership as a whole to fulfill its fiduciary duties to its stakeholders.

This structural relationship between the WTO's membership and its adjudicative bodies reflects a pervasive tension between judicial independence and political control and ties into the scholarly debate over whether to best characterize international judicial bodies as agents or trustees of their members. ${ }^{14}$ A growing scholarly consensus views the DSM as a trus-

take decisions by consensus. However, for establishment of a panel, adoption of panel and Appellate Body reports, and authorization of retaliation, the DSU provides that the DSB must adopt the decision unless there is a consensus against it. DSU arts. 6.1, 16.4, 17.5, 22.6. This decision-making procedure is referred to as negative or reverse consensus. FoOTER, supra note 8 , at 143 .

12. Although interpretations and findings developed within reports of the DSM only bind parties in the context of a specific dispute, many argue that a type of de facto stare decisis operates within the WTO. See, e.g., Zhu Lanye, The Effects of the WTO Dispute Settlement Panel and Appellate Body Reports: Is the Dispute Settlement Body Resolving Specific Disputes Only or Making Precedent at the Same Time?, 17 Temp. INT'L \& Comp. L.J. 221 (2003); Alec Stone Sweet \& Thomas L. Brunell, Trustee Courts and the Judicialization of International Regimes: The Politics of Majoritarian Activism in the European Convention on Human Rights, the European Union, and the World Trade Organization, $1 \mathrm{~J} . \mathrm{L}$. \& CTS. 61, 82 (2013) (arguing that the Appellate Body interprets and applies WTO agreements through "de facto adherence to precedent").

13. See, e.g., Ehlermann, supra note 6, at 302, 304 (arguing that the growing number of WTO Members will slow the political decision-making process even further).

14. See generally Karen J. Alter, Agents or Trustees? International Courts in their Political Context, 14 Eur. J. INT'L. ReL. 33 (2008) [hereinafter Alter, Agents or Trustees] (arguing that delegation to trustees is inherently different from delegation to agents, and that international courts such as the WTO DSM are more accurately categorized as trustees); Karen J. Alter, The Multiple Roles of International Courts and Tribunals: Enforcement, Dispute Settlement, Constitutional and Administratize Review, in INTERdisciplinARY PERSPECTIVES ON INTERnational Law and International Relations 345 (Jeffrey Dunoff et al. eds., 
tee-type judicial body in that (1) it possesses compulsory jurisdiction, (2) it acts as the authoritative interpreter of WTO law, and (3) it issues decisions which are "virtually impossible" for Members to reverse. ${ }^{15}$ Some even characterize the DSM as a type of "super-agent" in exercising its delegated authority to enforce WTO rules against its Members. ${ }^{16}$ Whether one views the DSM as a trustee or an agent of Members, the key issue underlying both approaches concerns the constituency of an international court: who the court is set up to serve and to whom the DSM owes a responsibility under a fiduciary theory of judging. As the actors who have delegated authority and powers to the DSM and whose interests the DSM is entrusted

2013) [hereinafter Alter, Multiple Roles] (describing four roles that states have delegated to the international courts they create); Clifford J. Carrubba, Matthew Gabel \& Charles Hankla, Judicial Behavior Under Political Constraints: Evidence from the European Court of Justice, 102 Am. PoL. Scr. Rev. 435 (2008) (providing empirical evidence contributing to the debate over how strongly member-state governments influence European Court of Justice rulings); Jacob Katz Cogan, Competition and Control in International Adjudication, 48 VA. J. INT'L. L. 411 (2008) (assessing the effectiveness of various types of control mechanisms available to states to influence the international courts they create); Darren G. Hawkins, David A. Lake, Daniel L. Nielson \& Michael J. Tierney, Delegation Under Anarchy: States, Intermational Organizations, and PrincipalAgent Theory, in Delegation and Agency in International. Organizations 3 (Darren G. Hawkins et al. eds., 2006) (adopting a principal-agent approach to theorize when and how states delegate authority to international organizations); Giandomenico Majone, Two Logics of Delegation: Agency and Fiduciary Relations in EU Governance, 2 EUR. UNION POL. 103 (2001) (describing the principal-agent and fiduciary (trustee) modes of delegation in the context of the European Union); Sweet \& Brunell, supra note 12 (describing the WTO Appellate Body as a trustee court and examining how it engages in majoritarian activism to help mitigate legitimacy problems).

15. Sweet \& Brunell, supra note 12, at 81-85; see also Alter, Agents or Trustees, supra note 14, at 38-43. But see Manfred Elsig, Principal-Agent Theory and the World Trade Organization: Complex Agency and 'Missing Delegation', 17 Eur. J. INT'L REL. 495 (2011) (conceptualizing the WTO as a complex agent using a principal-agent framework); Manfred Elsig \& Mark A. Pollack, Agents, Trustees, and International Courts: The Politics of Judicial Appointment at the World Trade Organization, 0 Eur. J. INT'L REL. 1 (2012) (arguing that the Appellate Body appointment process is deeply politicized, contrary to views of the Appellate Body as a trustee-type court largely beyond the influence of Members).

16. Sweet \& Brunell, supra note 12 , at 62. 
to serve, the WTO membership as a whole represents the DSM's beneficiaries, to whom it owes fiduciary duties. ${ }^{17}$

Under a fiduciary theory of judging-for courts characterized as either agents or trustees-judges have four fundamental duties: loyalty, care, the cluster of duties including candor, disclosure, and accounting, and, finally, the duty of deliberative engagement. ${ }^{8}$ This Article focuses on the fourth responsibility of judges-deliberative engagement-as applied to the WTO's adjudicative bodies. Deliberative engagement refers to the "affirmative duty" a court has to engage in a type of dialogue with those whose interests it holds in trust. ${ }^{19}$ This does not refer to a literal dialogue but rather to "being genuinely open to beneficiary preferences" and to provide reasoned decisions in response. ${ }^{20}$ Transferred to the WTO context, a fiduciary theory of judging implies that the DSM should seek to uncover the interests and preferences of a representative sample of the WTO membership or risk breaching obligations to its beneficiaries.

While the DSM possesses considerable interpretive authority and autonomy, the Marrakesh Agreement Establishing the World Trade Organization (Marrakesh Agreement) provides for two mechanisms through which DSM adjudicators

17. Id. at 63, 67 (discussing Ethan J. Leib, David L. Ponet \& Michael Serota, A Fiduciary Theory of Judging, 101 Cal.JF. L. Rev. 720 (2013)).

18. Leib, Ponet \& Serota, supra note 17 , at 731 . The advantage of a view of the judicial role grounded in fiduciary theory rests with its ability to move beyond the debate over whether courts are better characterized as agents or trustees, in that both categories are effectively types of fiduciaries. See Majone, supra note 14, for additional discussion of this debate. Whether a given court can be characterized as an agent or trustee will be a contextdependent question. Rather than focusing on this characterization, a fiduciary theory of judging allows us to elaborate upon and address the diverseand oftentimes conflicting-responsibilities of judges. See generally, Evan FoxDecent, The Fiduciary Nature of State Legal Authority, 31 QueEN's L. J. 259 (2005) (developing a fiduciary theory of state authority based on the nature of the relationship between a state and its subjects); Ethan J. Leib, David L. Ponet \& Michael Serota, Translating Fiduciary Principles into Public Law, 126 HARv. L. REv. 91 (2013) (arguing for and outlining the translation of private law principles of fiduciary duties to the public law context). For a critique of theories of judicial review that borrow from private law concepts of fiduciary relationships, see Seth Davis, The False Promise of Fiduciary Government, $89 \mathrm{No}$ TRE DAME L. REV. 1145 (2014).

19. Leib, Ponet \& Serota, supra note 17 , at 740.

20. Id. at 741,744 . 
may become apprised of Members' interpretive preferences at a given moment in time. These mechanisms of legislative feedback or response include amendment of the covered agreements ${ }^{21}$ and adoption of authoritative interpretations. ${ }^{22} \mathrm{Mem}$ bers thus formally possess the ability to specify what the law is or should be when they unanimously disagree with interpretations developed by the DSM, as well as in situations where WTO rules are unclear or permit multiple interpretations. However, these formal means of legislative response are difficult-if not impossible-to employ in practice. ${ }^{23}$ The adjudicative bodies are thus left without any effective counterbalance, raising the question of how the DSM may properly assess common interpretive views among Members in order to fulfill its fiduciary duty of deliberative engagement.

21. Marrakesh Agreement, supra note 11, art. X.

22. Id. art. IX:2. Although waivers under article IX:3 and art. IX:4 of the Marrakesh Agreement permit a Member to depart from an existing WTO obligation for a limited period of time, their purpose and effects differ from the formal mechanisms of legislative response discussed herein. First, waivers are intended to be temporary measures with limited duration and without lasting legal effect. Second, while a waiver does relieve a Member from a particular WTO obligation, it is "exceptional in nature, subject to strict disciplines and should be interpreted with great care," and thus cannot be taken as direct evidence of Members' views on the interpretation of WTO obligations or a "subsequent agreement" in the sense of art. 31(3)(a) of the Vienna Convention on the Law of Treaties. Appellate Body Report, European Communities-Regime for the Importation, Sale and Distribution of Bananas-Second Recourse to Article 21.5 of the DSU by Ecuador, II 382, WT/DS27/AB/RW2 (Nov. 26 2008); Appellate Body Report, European Communities-Regime for the Importation, Sale and Distribution of Bananas-Recourse to Article 21.5 of the DSU by the United States, II 380, 390, WT/DS27/AB/RW (Nov. 26 2008). Still, the WTO membership has sometimes used waivers in situations where a multilateral interpretation "could . . . have been more suitable," i.e. the so-called Kimberly Waiver granted in 2003. Ehlermann \& Ehring, supra note 4, at 815. The right to issue authoritative interpretations, also referred to as "Article IX:2 interpretations," endows Members with a tool to fill in interpretive gaps or ambiguities. Article IX:2 assigns the exclusive right to adopt authoritative interpretations to the highest political organs within the WTO-the Ministerial Conference $(\mathrm{MC})$ or the $\mathrm{GC}$-with adoption requiring a three-fourths majority, though consensus would likely be required in practice. See further, infra note 44 and accompanying text; Ehlermann \& Ehring, supra note 4, at 805-06.

23. See generally Ehlermann \& Ehring, supra note 4, at 813-18 (surveying various attempts to initiate the application of these formal means of legislative responses). 
Trade officials and scholars recognized the difficulty posed by the DSM's lack of an effective mechanism for deliberative engagement nearly a decade ago, when WTO Director General Supachai Panitchpakdi convened a Consultative Board to examine and address institutional challenges faced by the system. ${ }^{24}$ The resulting Sutherland Report on The Future of the WTO suggested that the DSB should play a "more constructive role ... with respect to criticisms of jurisprudence." 25 While many of the reform proposals contained within the Sutherland Report had the potential to address the growing institutional imbalance within the WTO and to enable the DSM to fulfill its fiduciary duties, nearly ten years later Members have made no significant efforts to turn these proposals into a reality. ${ }^{26}$

The DSM's inability to fulfill its duty of deliberate engagement with the full membership stems partly from the fact that only the interpretive views of parties and third parties pleaded during the course of dispute proceedings officially reach the DSM. ${ }^{27}$ This implies that dispute panels and the $\mathrm{AB}$ are formulating interpretations of WTO rules based on incomplete information about all of the Members' preferences, as only a handful of Members have participated in disputes before the DSM. ${ }^{28}$ Accordingly, although it remains to be studied empirically, the DSM's interpretations are likely biased in favor of a

24. See Report by the Consultative Board to the Director-General Supachai Panitchpakdi, The Future of the WTO: Addressing Institutional Challenges in the Netw Millenium, 49-59 (2005) [hereinafter the Sutherland Report] (providing an appraisal and recommendations for improvement of the WTO Dispute Settlement System); see also Ehlermann \& Ehring, supra note 4, at 820 (noting that the approach should not be abused as that would expose the jurisprudence of the Appellate Body to review and harm the Appellate Body's independence).

25. Sutherland Report, supra note 24, II 250.

26. William J. Davey, The WTO and Rules-Based Dispute Settlement: Historical Evolution, Operational Success, and Future Challenges, 17 J. INT'L ECON. L. 679, 693 (2014) [hereinafter Davey, Rules-Based Dispute Settlement] (discussing this concern within the Sutherland Report and noting a decade later that there was still "a need for some way for the political system to ensure that the negotiated rules are appropriately interpreted").

27. Marc L. Busch \& Eric Reinhardt, Three's a Crowd: Third Parties and WTO Dispute Settlement, 58 WORL D POL. 446 (2006) (finding that panel and Appellate Body decisions appear to be influenced by third party participation).

28. See infra Table 1. 
powerful minority: the handful of economically and politically influential countries that participate actively within the dispute settlement system..$^{29}$ An existing practice within the DSB-the expression of views prior to the adoption of panel and $A B$ reports-could address this deficiency. ${ }^{30}$ Government representatives can and often do use these statements both to express views on the reports and to address systemic issues and broader jurisprudential developments.

DSB statements in no way legally bind the WTO's quasijudicial bodies, particularly given that Members often voice widely divergent views on the same issue. Rather, they fulfill an important informational function, in that they make interpretive preferences of Members available for consideration by the DSM. However, an unrepresentative subset of countries make statements in this context, ${ }^{31}$ which suggests that the DSM is only fulfilling its duty of deliberative engagement (to consider its beneficiaries' preferences) with respect to a minority of Members. In order to remedy this and to assist the WTO's adjudicative bodies in fulfilling their delegated role, this Article outlines how Members can improve the normative guidance received by the DSM by adopting a more widespread and forward-looking practice of expressing views before the DSB adopts panel or $A B$ reports. This will encourage less active countries within the dispute settlement system to familiarize themselves with WTO rules and jurisprudence and, more importantly, improve the functioning of the DSM by aiding its duty to fulfill its fiduciary obligations to all Members.

This Article proceeds as follows: Following this introduction, Section II outlines the formal mechanisms of legislative response available to Members under the WTO Agreement, focusing on Members' exclusive right to adopt authoritative interpretations. It examines the few unsuccessful efforts to adopt such interpretations and discusses how the non-use of Article IX:2 contributes to an institutional imbalance between

29. See Henrik Horn, Louise Johannesson \& Petros C. Mavroidis, The WTO Dispute Settlement System 1995-2010: Some Descriptive Statistics, 45 J. WORI.do Trade 1107 (2011) (providing an overview of the countries that use the dispute settlement system).

30. Prior to the adoption of reports by the DSB, any Member representative retains the right to make statements on their record that "express their views on a ... report." DSU, supra note 5 , arts $16.4,17.14$.

31. See infra Table 3. 
the WTO's political and adjudicative bodies not intended by Members when drafting the WTO Agreement. We then demonstrate how Members may functionally circumvent this inability to engage in legislative response, by providing normative guidance to the WTO's adjudicative organs through their $D S B$ statements on panel and $A B$ reports. Drawing on an original dataset of all report statements made within the DSB from 1995 to 2012 and a series of interviews with Member representatives and WTO Secretariat officials, ${ }^{32}$ Section III examines the use of this informal mechanism to date. It demonstrates that Members that express report views do not constitute a representative sample of the WTO membership as a whole, along critical and relevant characteristics. This suggests that report statements currently provide panels and the $\mathrm{AB}$ with a skewed picture of the membership's views on certain jurisprudential developments. In order to remedy this, Section IV proposes that a broader range of Members actively formulate and express views, individually or jointly, prior to report adoption. This section also addresses potential obstacles to or limitations of this proposal. Section $V$ concludes by briefly discussing why this proposal is normatively desirable at this time.

\section{Legislative Response Within the WTO}

The WTO relies on a decentralized form of enforcement, with governments challenging other Members' domestic laws and policies within the dispute settlement system. Member governments formally adopt dispute rulings and issue implementation recommendations under a "reverse consensus" rule, ${ }^{33}$ but the primary responsibility for clarifying WTO rules and interpreting the scope of international trade authority

32. A total of twenty-nine interviews were conducted during 13-17 January 2014 in Geneva, Switzerland. Three interviewees were officials within the WTO Secretariat; twenty-five interviews were conducted with current or former delegates representing their respective Members within DSB meetings; one interview was conducted with a representative from the Advisory Centre on WTO Law, an independent organization that provides legal advice and assistance to developing and least-developed countries. Members interviewed varied across relevant characteristics, including size, wealth, use of the dispute settlement system, and vocal participation within meetings of the DSB. The identities of all interviewees have been redacted and replaced with random numbers, to ensure interviewee confidentiality.

33. See supra note 11 and accompanying text. 
rests with panels and the Appellate Body. Member governments are bound by these decisions, face retaliatory concessions if they do not comply with their rulings, and as a result, most governments do eventually make costly changes to domestic laws and regulations to bring their measures into compliance. ${ }^{34}$

Under the WTO Agreement, Members possess two mechanisms of legislative response to interpretations articulated by the DSM: Article $\mathrm{X}$ amendments of the covered agreements and Article IX:2 authoritative interpretations. In this Article, "legislative response" refers to the response of the WTO's political bodies-the membership as a whole-to interpretations or practices of its adjudicative bodies that are perceived to be at odds with governments' intention, will, or preferences. ${ }^{35}$ Within the domestic context, mechanisms of legislative response play a similarly important role in ensuring accountability between branches of government and minimizing the "countermajoritarian difficulty" of unaccountable judges overruling the "will of the legislature." ${ }^{36}$ Reversals of interpreta-

34. For discussions of rates of compliance with DSM rulings, see generally William J. Davey, The WTO Dispute Settlement System: The First Ten Years, $8 \mathrm{~J}$. INT'L ECON. L. 17 (2005) (finding that although performance in terms of compliance with time frames has been quite unimpressive, the DSM has overall been successful in settling disputes); Davey, Rules-Based Dispute Settlement, supra note 26 (assessing the effectiveness of the DSS, and, in particular, compliance with decisions by the major trade WTO powers, the U.S., EU and China); Bruce Wilson, Compliance by WTO Members with Adverse WTO Dispute Settlement Rulings: The Record to Date, 10 J. INT'L ECON. L. 397 (2007) (arguing that compliance rates with DSM rulings are overall high, and that the U.S. and the EU, despite some difficulties, generally have succeeded in complying with panel and Appellate Body decisions). But see William J. Davey, Compliance Problems in WTO Dispute Settlement, 42 Connell. INT'L. L.J. 119 (2009) (examining problems related to the quality and timeliness of compliance and proposing reforms to tackle them).

35. See generally Richard E. Neustadt, Presidential Power and the Modern Presidents: The Pol.ticics of Leadership from Roosevelt to ReaGAN 34 (1990) (providing an overview of scholarship in the American context that focuses on the ongoing interaction among "separated institutions sharing power"); see also Jeb Barnes, Bringing the Courts Back In: Interbranch Perspectives on the Role of Courts in American Politics and Policymaking, 10 ANN. Rev. Pol. Scr. 25 (2007) (reviewing studies in the American context that approach the study of courts from an "interbranch perspective" and policymaking as emanating from interaction among overlapping forums).

36. Allexander Bickel, The Least Dangerous Branch: The Supreme Court at the Bar of Politics 16 (2d ed. 1962). See also John H. Ely, De 
tions do not occur on a daily basis at the domestic level, but the availability of legislative response does provide an important mechanism to secure a majoritarian check on what the law is or should be.

While the domestic model is not directly transposable to the international level, where a decentralized system is recognized and accepted, ${ }^{37}$ legislative response still provides a useful reference point to ensure proper functioning of an institution. More importantly, it likely enhances the quality and representativeness of decision making undertaken by various branches by encouraging a continuing and dynamic "dialogue" over the meaning of the law. ${ }^{38}$ Even the strongest supporters of the juridification of the multilateral trading system have not advocated for relinquishing all political or diplomatic input into the activities of the DSM. ${ }^{39}$ Given the WTO's ambition to function as a Member-driven organization and to facilitate cooperative international economic relations, it is just as important as in the domestic context that governments make use of the WTO Agreement's legislative response mechanisms to provide normative guidance to the adjudicative bodies tasked with clarifying WTO rules and facilitating the resolution of trade disputes.

MOCRACY AND Distrust: A Theory of Judicial. Revilw 4-5 (1980) (pointing to concerns over (domestic) courts' overruling the lawmaking branches' decisions, in that courts are not elected by the people or are not otherwise politically accountable); William N. Eskridge, Dynamic Statutory Interpretation 135 U. Pa. L. Rev. 1479, 1525 (1987) (citing Guido Caldarresi, A ComMON LAW FOR THE AGE OF STATUTEs (1982)) (arguing that even in the domestic context, "legislative inertia" often leaves the "countermajoritarian difficulty unsolved, but ameliorated").

37. Dominic Raab \& Hans Bevers, The International Criminal Court and the Separation of Powers, 3 InT'L ORG. L. Rev. 93, 98 (2006).

38. See Barry Friedman, Dialogue and Judicial Review, 91 Mıch. L. Rrv. 577, 654 (1993) (describing how American judicial decisions frame dialogues about the law); Raab \& Bevers, supra note 37, at 133 (noting how newly established working groups are helping to enhance dialogue between the ICC and States Parties). See generally Louis Fisher, Constitutional Dialogues: Interpretation as Political Process (1988) (arguing that constitutional interpretation and development emerges from a dialogue among the executive, legislative, and judicial branches of government).

39. See, e.g., Robert L. Howse, The Most Dangerous Branch? WTO Appellate Body Jurisprudence on the Nature and Limits of the Judicial Power, in THE ROLE: OF the Judge in International Trade Regulation: Explerience and Lissons FOR THE WTO 11 (Thomas Cottier et al., eds., 2003). 
The power to adopt Article $\mathrm{X}$ amendments represents a clear ability to re-contract, since amendments may add to, alter, or diminish existing rights and obligations. ${ }^{40}$ The procedures for amending the various WTO agreements are fairly complex and differ according to the agreement and provision at issue. ${ }^{41}$ In practice, the amendment procedure does not make for an efficient mechanism of legislative response, as the process is understandably lengthy. ${ }^{42}$ For example, the first treaty amendment agreed upon by WTO Members-the Protocol Amending the Agreement on Trade-Related Aspects of Intellectual Property Rights adopted in 2005-is not currently in effect, with two thirds of the WTO's Members yet to formally deposit an instrument of acceptance with the Director General. ${ }^{43}$

The right to issue Article IX:2 interpretations endows Members with a more practical tool to implicitly re-contract, not by altering existing rights or obligations but by filling in interpretive gaps or ambiguities. ${ }^{44}$ This provides governments with the authority to shape future dispute settlement jurispru-

40. Members may seek an amendment for reasons other than legislative response, such as to address time-inconsistent preferences on international trade or in response to changes in the uncertain environment of international economic relations. See Barbara Koremenos, Contracting Around International Uncertainty, 99 AM. PoL. Sci. Rev. 549 (2005).

41. See Marrakesh Agreement, supra note 11, art. X (outlining the various procedures for amending WTO agreements and provisions).

42. See Hunter Nottage \& Thomas Sebastian, Giving Legal Effect to the Results of WTO Trade Negotiations: An Analysis of the Methods of Changing WTO Law, 9 J. INT'L EcON. L. 989, 991-94 (2006) (detailing the cumbersome amendment process, including the various procedural obstacles that delay amendments, and limited application of amendments that normally only take effect for members who have accepted them).

43. General Council, Amendment of the TRIPS Agreement: Decision of $6 \mathrm{De}$ cember 2005, WT/L/64l (Dec. 8, 2005); WTO, Members Accepting Amendment of the TRIPS Agreement (Oct. 2, 2011), http://www.wto.org/english/tratop_e/ trips_e/amendment_e.htm (providing a list of Members that have deposited instruments of acceptance with the WTO's Director General).

44. The Appellate Body has noted that an art. IX:2 interpretation is "meant to clarify the meaning of existing obligations, not to modify their content" and "can be likened to a subsequent agreement regarding the interpretation of the treaty or the application of its provisions pursuant to Article 31 (3) (a) of the Vienna Convention, as far as the interpretation of the WTO agreements is concerned." Appellate Body Report, European CommunitiesRegime for the Importation, Sale and Distribution of Bananas-Second Recourse to Article 21.5 of the DSU by Ecuador, supra note 22, at III $350,383$. 
dence if it begins to move away from WTO Members' interpretive preferences. Article IX:2 assigns the exclusive right to adopt authoritative interpretations to the Ministerial Conference or the General Council (GC), with adoption requiring a three-fourths majority, though consensus would likely be required in practice. ${ }^{45}$ While the WTO Agreement does not specify their legal effects, the $A B$ has noted that such interpretations have "a pervasive legal effect" and are "binding on all Members," and therefore on panels and the $\mathrm{AB}$ as well. ${ }^{46}$ This is one of the fundamental differences between Article IX:2 interpretations and interpretations undertaken by the DSM in the course of dispute settlement, which only formally bind the parties to a given dispute. ${ }^{47}$ Article IX:2 thus grants WTO Members an opportunity to refine and shape the interpretation of existing rules, with the effect of determining the scope of rules prospectively as well as correcting future applications of interpretations contained within adopted reports.

Articles IX:2 and X of the WTO Agreement encourage a type of deliberative engagement between Members and the DSM bodies. This is particularly important given the difficulty (if not impossibility) of blocking report adoption, due to the reverse consensus rule. Because reports of panels and the $A B$ have significant political and economic implications for the membership as a whole, the ability of Members to respond to their decisions encourages a dialogical relationship with the DSM about Members' rights and obligations under the covered agreements.

Since the establishment of the World Trade Organization almost twenty years ago, Members have made a few efforts to employ Article IX:2 interpretations but none have been adopted to date. On 21 January 1999, the European Communities (EC) requested an authoritative interpretation regarding the relationship between Articles 21.5 and 22 of the Dispute Settlement Understanding (DSU) and called for a special meeting of the GC to consider this "sequencing issue." 48 The

45. Ehlermann \& Ehring, supra note 4, at 804-05.

46. Appellate Body Report, United States-Measures Affecting the Production and Sale of Clove Cigarettes, II 250, WT/DS406/AB/R (Apr. 4, 2012).

47. Appellate Body Report, United States-Final Anti-Dumping Measures on Stainless Steel from Mexico, 66 n. 308, WT/DS344/AB/R (Apr. 30, 2008).

48. Request for an Authoritative Interpretation Pursuant to Article IX:2 of the Marrakesh Agreement Establishing the World Trade Organization, 
GC did not adopt the requested interpretation, with the Chairman instead suggesting that the DSB consider the issue. ${ }^{49}$ Three years later, several countries proposed that the GC adopt an Article IX:2 interpretation on Article 30 of the Trade-Related Aspects of Intellectual Property Rights (TRIPS) Agreement. ${ }^{50}$ Ultimately, Members first made use of a waiver ${ }^{51}$ and subsequently formally amended the treaty. ${ }^{52} \mathrm{~A}$ few governments within the DSU Review negotiations have suggested employing authoritative interpretations to clarify certain aspects of the DSU and provide normative guidance to the DSM regarding, inter alia, discretionary law theory, the sequencing issue, and provisions affecting developing countries, though to date no authoritative interpretations have been adopted. ${ }^{53}$

Communication from the European Communities, WT/GC/W/133 (Jan. 25, 1999); Request for an Authoritative Interpretation Pursuant to Article IX:2 of the Marrakesh Agreement Establishing the World Trade Organization, Communication from the European Communities, WT/GC/W/143 (Feb. 5 1999). The United States opposed the request, arguing that the proposed interpretation would effectively be an amendment and thus would contradict the prohibition on undermining the amendment procedure. See Response to European Communities' Request for an Authoritative Interpretation of the Dispute Settlement Understanding Pursuant to Article IX:2 of the WTO Agreement, Communication from the United States, 3, WT/GC/W/144 (Feb. 5, 1999).

49. Minutes of Meeting held in the Centre William Rappard on 15 and 16 February 1999, at 30, If 6(a), WT/GC/M/35 (Mar. 30, 1999).

50. Council for Trade-Related Aspects of Intellectual Property Rights, Concept Paper Relating to Paragraph 6 of the Doha Declaration on the TRIPS Agreement and Public Health, Communication from the European Communities and their member States, II 23-31, IP/C/W/339 (Mar. 4, 2002); Council for Trade-Related Aspects of Intellectual Property Rights, Paragraph 6 of the Ministerial Declaration on the TRIPS Agreement and Public Health, II 6-13, IP/C/W/355 (June 24, 2002); Council for Trade-Related Aspects of Intellectual Property Rights, Proposals on Paragraph 6 of the Doha Declaration on the TRIPS Agreement and Public Health: Thematic Compilation, 13, 16, IP/C/W/363 (July 11, 2002).

51. Implementation of Paragraph 6 of the Doha Declaration on the TRIPS Agreement and Public Health, Decision of the General Council of 30 August 2003, WT/ L/540 and Corr. 1 (Sept. 1, 2003).

52. Amendment of the TRIPS Agreement: Decision of 6 December 2005, WT/L/64l (Dec. 8, 2005).

53. See, e.g., Special Session of the Dispute Settlement Body, Negotiations on Improvements and Clarifications of the Dispute Settlement Understanding, 3, TN/ DS/W/22 (Oct. 28, 2002) (proposition by Japan to "make an exception to the application of the 'discretionary law' theory when repetition of the same violation is highly probable"); Special Session of the Dispute Settlement Body, Minutes of Meeting held on 21 May 2002, I 29, TN/DS/M/2 (July 3, 
Similarly, WTO Members have not employed Article IX:2 interpretations in instances where we might have expected responses to jurisprudential developments disfavored by the majority of Members. For example, when panels and the $A B$ began accepting unsolicited amicus curiae briefs, Members merely criticized the practice during the course of a GC meeting. ${ }^{54}$ In Australia-Automotive Leather $I I,{ }^{55}$ the Article 21.5 compliance panel's interpretation of "withdraw the subsidy" under Article 4.7 of the Agreement on Subsidies and Countervailing Measures (SCM) likewise elicited strong criticism from a large number of Members, ${ }^{56}$ but no authoritative interpretation was sought. One likely explanation for the non-use of authoritative interpretations is the WTO's customary practice of consensus decision-making. While Members may be able to

2002) (noting Bulgaria's interest in cooperating with other parties on finding a solution to the sequencing issue); Special Session of the Dispute Settlement Body, Minutes of Meeting held on 15 July 2002, I 8, TN/DS/M/3 (Sept. 9,2002 ) (noting Bulgaria's interest in resolving the problem of sequencing through an authoritative interpretation of the relevant provisions of the DSU); Special Session of the Dispute Settlement Body, Minutes of Meeting held on 10 September 2002, II 56, TN/DS/M/4 (Nov. 6, 2002) (noting the proposal from Kenya on behalf of the African Group for the benefit of all developing countries calling for an authoritative interpretation of the DSU to allow for strengthening the technical assistance programs, collective retaliation, employing the use of special procedures relating to resource constraints in addition to time-frames, and making legal expertise available); Special Session of the Dispute Settlement Body, Minutes of Meeting held on 14 October 2002, I 12, TN/DS/M/5 (Feb. 27, 2003) (noting Japan's proposal to create an exception to the application of the "discretionary law" theory when repetition of the same violation was highly probable through an authoritative interpretation of Article XVI:4 of the Marrakesh Agreement Establishing the WTO); Special Session of the Dispute Settlement Body, Minutes of Meeting held on 1315 November 2002, II 3, TN/DS/M/6 (Mar. 31, 2003) (noting Japan's belief that abuse of the "discretionary law" theory was a real possibility requiring a resolution and supporting the use of an authoritative interpretation of Article XVI:4 of the Marrakesh Agreement Establishing the WTO to amend the relevant WTO provisions and create an exception to the "discretionary law" theory).

54. Minutes of Meeting Held in the Centre William Rappard on 22 November 2000, II $16,22,31,40,49,70,83,89,98,112$, WT/GC/M/60 (Jan. 23, 2001).

55. Panel Report, Australia-Subsidies Provided to Producers and Exporters of Automotive Leather - recourse to Article 21.5 of the DSU by the US, WT/DSI26/ RW (Jan. 21, 2000).

56. Dispute Settlement Body, Minutes of Meeting Held in the Centre William Rappard on 11 February 2000, pp. 5-9, WT/DSB/M/75 (Mar. 7, 2000). 
agree on what constitutes an incorrect interpretation, this does not necessarily imply they would be able to reach a consensus on the appropriate authoritative interpretation to adopt.

Given the non-use of Article XI:2, the DSM essentially enjoys complete interpretive autonomy from the political bodies of the Organization. This has led some to observe that the political decision-making process of the WTO appears "weak and inefficient" compared to its dispute settlement process ${ }^{57}$ and that the non-use of authoritative interpretations has been "uncomfortable for the dispute settlement system, notably the AB, who is aware that mistakes or disapproved legal interpretations will not be corrected." 58 The non-use of legislative response mechanisms within the WTO has effectively given decisions of the $\mathrm{AB}$ "a kind of de facto finality as interpretations of law, even if they lack de jure finality." 59

The practice of consensus decision-making within the WTO has raised some concerns about the institutional balance between the Organization's political and adjudicative bodies, leading to multiple reform proposals over the years. In December 2002, Chile and the United States (U.S.) issued a joint proposal in the context of DSU Review negotiations to address Member concerns that "some limitations in the current procedures may have resulted, in some cases, in an interpretative approach or legal reasoning applied by WTO adjudicative bodies ... that could have benefitted from additional Member review."60 They suggested that Members might provide additional interpretive guidance through, among other mechanisms, the "partial adoption" of reports. ${ }^{61}$ Although controversial among Members, the proposal did garner some support

57. Ehlermann, supra note 6, at 302.

58. Ehlermann \& Ehring, supra note 4, at 819.

59. Howse, supra note 39, at 15. Panels have made clear that they will follow the Appellate Body's prior interpretations unless confronted with "cogent" reasons to reach a different conclusion, which would include an art. IX:2 interpretation. See Panel Report, United States-Countervailing and AntiDumping Measures on Certain Products from China, If 7.317, WT/DS449/R (Mar. 27, 2014).

60. Special Session of the Dispute Settlement Body, Negotiations on Improvements and Clarifications of the Dispute Settlement Understanding on Improving Flexibility and Member Control in WTO Dispute Settlement, Communication by Chile and the United States II 2, TN/DS/W/28 (Dec. 23, 2002).

61. Id. at I 6(c). 
and remains on the agenda of DSU Review discussions. ${ }^{62}$ More critically, it clearly reflects a concern that interpretations within dispute reports are difficult if not impossible to change through legislative response by the Members. Others have proposed to make authoritative interpretations more operational in practice, to provide both Members and the adjudicative bodies "normative guidance in the context of ambiguous rules, instead of resorting to dispute settlement." 63 While a laudable goal, it is highly unlikely that this mechanism, which to date has never been employed, will ever function as envisioned by the founders of the WTO.

Although it is debatable and far beyond the scope of this Article to assess whether the non-use of legislative response weakens the DSM's legitimacy, the fact that the WTO's adjudicative bodies are left with few systematic or efficient feedback mechanisms is worrisome from a normative perspective. ${ }^{64}$

62. World Trade Organization, Annual Report 2013, 32 (2013) (indicating that Member-control and flexibility, including whether to allow deletion of parts of panel reports by parties, were still under discussion during DSU negotiations in 2013). Subsequent Annual Reports of the WTO do not specifically refer to the issue of "partial adoption," but emphasize that "[f]urther work is ... ongoing on flexibility and member-control." World Trade Organization, Annual Report 2014, 38 (2014)). Support for this proposal came primarily from Hong Kong, Malaysia and Singapore. See Thomas A. Zimmermann, Negotiating the Review of the WTO Dispute Settlement UnderSTANDING 116 (2006). India and Jordan also expressed early tentative support for the proposal. See Special Session of the Dispute Settlement Body, Minutes of Meeting held on 28-30 January 2003, II 12, 15, TN/DS/M/8 (June $30,2003)$. In addition, some Members expressed support for this proposal within interviews. See, e.g., Interview 5.5, in Geneva, Switz. (Jan. 17, 2014). For opposition to this proposal, see Daniel Pruzin, U.S. Proposal on Dispute Settlement Reform Gets Mixed Reaction from WTO Delegations, WTO RFPORTER (Dec. 20 2002), http://news.bna.com/wtln/WTLNWB/split_display.adp? fedfid $=9297363 \&$ vname $=$ wtobulallissues $\& \mathrm{fcn}=2 \&$ wsn $=520450000 \& \mathrm{fn}=92973$

63\&split=0; US-Chile Text For DSU Changes Leaves Out Standard of Review, INSIDE US TRADE, Mar. 14, 2003. One interviewee indicated that his country supported increased flexibility, but expressly noted the lack of consensus within the membership to adopt the proposal. See Interview 4.7, in Geneva, Switz. (Jan. 16, 2014).

63. Ehlermann \& Ehring, supra note 4, at 813.

64. While it could be argued that interim review does provide an efficient feedback mechanism, it is limited to the parties' preferences and does not shed light on the preferences of the membership as a whole. Third-party participation within disputes could potentially contribute to enhancing the representativeness of views made available to the DSM, but interviews revealed that many third parties find it difficult to actively participate in pro- 
Members' non-use of authoritative interpretations raises the question of how the DSM can assess common interpretive views or practices among all WTO Members. To put it differently, non-use of formal legislative response leaves unspecified the means through which the membership as a whole and the DSM do and should engage in deliberative engagement. In order to address this shortcoming, we argue that Members should increase reliance on an existing practice-the expression of views prior to adoption of panel and Appellate Body reports within DSB meetings-as a functional substitute for formal legislative response. The legal effects of these two mechanisms-authoritative interpretations and expression of views-differ significantly, in that the former bind future dispute settlement proceedings while the latter do not. However, both tools fulfill the underlying goal of providing to the DSM feedback, guidance, and information on Members' interpretive preferences.

\section{Expression of Views Prior to Report Adoption: Current Practices}

The WTO Agreement formally provides Members with the ability to shape interpretation of the covered agreements through Article XI:2, but this mechanism is not utilized in practice and there is considerable reason to doubt it will ever operate effectively. Yet its intended function-legislative response-is an important one. From both an institutional and a normative perspective it is critical that the DSM be aware of interpretive views held by a representative cross-section of the WTO membership. Declarations adopted and views expressed by governments within the WTO's various committees provide one indirect way in which the DSM could become apprised of Members' views on the meaning or interpretation of provisions within covered agreements. ${ }^{65}$ These may be helpful

ceedings and are often, due to capacity constraints, relegated to passive observers. See, e.g., Interview 2.1, in Geneva, Switz. (Jan. 14, 2014); Interview 5.5 , supra note 62 .

65. See Schaffer \& Trachtman, supra note 8 , at 15 . For instances in which the DSM has referred to the views of WTO committees, see, for example, Panel Report, European Communities-Anti-Dumping Duties on Malleable Cast Iron Tube or Pipe Fittings from Brazil, II 7.100, 7.321, WT/DS219/R (Mar. 7, 2003); Appellate Body Report, European Communities-Anti-Dumping Duties on Malleable Cast Iron Tube or Pipe Fittings from Brazil, I 80, n.73, WT/DS219/AB/ 
when considering provisions not previously interpreted, but are less informative in terms of providing a systematic way for the DSM to assess Member consensus or dissensus over interpretations already articulated.

We argue that views expressed in statements made prior to report adoption within the DSB have the potential to fulfill this function. These views could provide the DSM with a wealth of information about Members' interpretive preferences to which it can refer, if it so chooses, in future disputes. This section describes the current practice of views expressed on reports in the WTO, drawing on an original dataset of statements made within meetings of the DSB between 1995 and 2012 and a series of interviews with Member representatives and WTO Secretariat officials. It highlights the current deficiencies in and limitations on the use of report statements to date, before turning to proposals for improving the practice to enable the DSM to better fulfill its fiduciary duty of deliberative engagement with Members.

\section{A. Procedure and Purpose of Statements on Dispute Reports}

Panels and the Appellate Body report their findings directly to Members in plenary sessions of the General Council sitting as the DSB. These reports do not directly bind parties to the dispute, but must be adopted by the DSB, which then issues implementation recommendations that create the second-order legal obligations in terms of compliance. ${ }^{66}$ While the DSU does not expressly create a right for government representatives to express report views, it does provide that the report adoption procedure is "without prejudice to the right of Members to express their views." 67 In practice this has taken the form of statements by interested governments made on the record of a DSB meeting, following which the report is adopted under the reverse consensus rule. ${ }^{68}$ Panel reports must be adopted or appealed within sixty days of their date of circulation; if one or more parties decide to appeal the report,

$\mathrm{R}$ (July 22, 2003) (relying on a recommendation issued by the Anti-Dumping Committee to interpret the requirement of an investigation period within anti-dumping investigations).

66. DSU arts. 19, 21.1.

67. Id. arts. $16.4,17.14$.

68. See supra text accompanying note 11 . 
they typically postpone its consideration by the DSB until the conclusion of the appellate proceeding. ${ }^{69}$ For this reason, many panel reports have not been discussed by the DSB separate from their consideration prior to adoption of the $A B$ report.

Members have engaged in little explicit discussion of the purpose of statements made prior to report adoption. Most invariably stress that the right to make report statements does not undermine parties' unconditional acceptance of adopted report findings. ${ }^{70}$ Some have noted that such views "may furnish cogent reasons that would ultimately lead to further clarification of the issues in question," 71 and that such discussion is critical in terms of providing structured feedback "in the interest of the long-term viability and health of the dispute settlement system."72 Within interviews, several representatives similarly noted that the right to make report statements provides an opportunity for the membership to inform the Secretariat and ultimately the $\mathrm{AB}$ about its views on both jurisprudence and the conduct of dispute proceedings. ${ }^{73}$ The expression of report views thus serves a similar purpose to that of Article IX:2 authoritative interpretations, in that both create a feedback mechanism to assist the DSM in ascertaining and assessing Members' interpretive preferences. They differ significantly in that, unlike Article IX:2 interpretations, Members' report statements are not legally binding upon other Members, panels, or the $\mathrm{AB} .{ }^{74}$ In this difference, however, lies the strength of this mechanism in fulfilling its proposed informa-

69. Bozena Mueller-Holyst, The Role of the Dispute Settlement Body in the Dispute Settlement Process, in Key Issues in WTO Dispute Settrlement: THE First TEN Years 25, 27 (Rufus Yerxa et al., eds., 2005).

70. See, e.g., Dispute Settlement Body, Minutes of Meeting held on 1 August 2008, II 71-88, WT/DSB/M/254 (Oct. 22, 2008).

71. Id. I 76 .

72. Dispute Settlement Body, Minutes of Meeting held on 23 May 1997, at 510, WT/DSB/M/33 (June 25, 1997).

73. Interview 1.1, in Geneva, Switz. (Jan. 13, 2014); Interview 2.4, in Geneva, Switz. (Jan. 14, 2014); Interview 5.5, supra note 62.

74. Appellate Body Report, United States-Continued Suspension of Obligations in the EC Hormones Dispute, II 398-99, WT/DS320/AB/R (Oct. 16, 2008) (noting that "DSB statements are not intended to have legal effects and do not have the legal status of a definitive determination in themselves. Rather, they are views expressed by Members and should not be considered to prejudice Members' position in the context of a dispute"). 
tional role. Precisely because such statements are not legally binding, Members may be less restrained in elaborating on their interpretive views than when attempting to reach consensus in order to adopt an authoritative interpretation.

\section{B. Overview of Report Statement Practices}

While the WTO Agreement permits all Members to express report views, in practice only a select group of governments make use of this opportunity and even these do not make full use of its potential to act as a constructive feedback mechanism. Between 1995 and 2012, the DSB has considered and adopted 169 reports (see Table 1), with an average of 9.39 reports adopted per year. Members have made a total of 1,038 statements expressing views on these reports (11.3 per cent of all statements made within DSB meetings), with an average of 6.14 statements made per report and an average of $5.57 \mathrm{Mem}-$ bers expressing views prior to report adoption. On very rare occasions, parties to the dispute also circulate written report statements. ${ }^{75}$ Overall, only thirty-nine per cent of the WTO membership in 2012 (fifty-one Members in total) has expressed at least one view on an $\mathrm{AB}$ report, with the percentage even smaller for panel or Article 21.5 reports. ${ }^{76}$

75. See, e.g., Dispute Settlement Body, Communication by Mexico, United States-Anti-Dumping Act of 1916, WT/DS162/8 (July, 26, 2000) (written statement by Mexico expressing its "deep concern . . . with regard to the handling of the Panel Report in United States - Anti-Dumping Act of 1916").

76. Percentage of membership calculated excluding all EU member states, as only the EU representative may express views or make statements within the DSB. See Interview 1.2, in Geneva, Switz. (Jan. 13, 2014); Interview 1.3, in Geneva, Switz. (Jan. 13, 2014). 
TABLE 1: WTO Dispute Reports Adopted, 1995-2012**

\begin{tabular}{|l|c|c|c|c|}
\hline & $\begin{array}{l}\text { Reports } \\
\text { Adopted }\end{array}$ & $\begin{array}{l}\text { Total Report } \\
\text { Statements }\end{array}$ & $\begin{array}{l}\text { Average } \\
\text { Statements } \\
\text { per Report }\end{array}$ & $\begin{array}{l}\text { \% Members } \\
\text { Represented* }\end{array}$ \\
\hline \hline Panel Reports & 49 & 221 & 4.43 & $\begin{array}{c}27 \% \\
(36 \text { Members })\end{array}$ \\
\hline $\begin{array}{l}\text { Appellate Body } \\
\text { \&c Panel } \\
\text { Reports }\end{array}$ & 92 & 641 & 6.97 & $\begin{array}{c}39 \% \\
(51 \mathrm{Members})\end{array}$ \\
\hline $\begin{array}{l}\text { Art. 21.5 } \\
\text { Reports }\end{array}$ & 28 & 180 & 6.43 & $\begin{array}{c}24 \% \\
(31 \mathrm{Members})\end{array}$ \\
\hline \hline GATT, GATS & 32 & 210 & 6.56 & $\begin{array}{c}27 \% \\
(36 \mathrm{Members})\end{array}$ \\
\hline $\begin{array}{l}\text { ADA, SCM, } \\
\text { TBT }\end{array}$ & 61 & 350 & 5.74 & $\begin{array}{c}25 \% \\
(33 \mathrm{Members})\end{array}$ \\
\hline $\begin{array}{l}\text { All other } \\
\text { Agreements }\end{array}$ & 48 & 298 & 6.21 & $\begin{array}{c}33 \% \\
(43 \mathrm{Members})\end{array}$ \\
\hline
\end{tabular}

*Percentage of Members Represented calculated excluding all E.U. member states. Figures on agreement type calculated only for panel and Appellate Body reports (excluding Art. 21.5 reports).

**Source: Authors' dataset of all statements made within the WTO Dispute Settlement Body from 1995-2012. Minutes of DSB meetings obtained from the WTO's Documents Online system.

Members express fewer total views on panel reports than $\mathrm{AB}$ or Article 21.5 compliance proceeding reports, although views expressed on $\mathrm{AB}$ reports do often reference panel findings. The average number of statements does not differ considerably across the trade agreement(s) interpreted within the report. This pattern is consistent across time and contingent on the type of disputes empaneled. Reports interpreting newer disciplines do not elicit significantly more statements than those interpreting agreements with fairly established preWTO jurisprudence (such as the GATT). This suggests that Members do not presently use these statements as an explicit means to provide views on newly interpreted provisions, for which the DSM might benefit from additional guidance on governments' interpretive preferences. 


\section{Trends in the Use of Report Statements}

Participation within DSB meetings varies across Members in predictable ways, since not all countries are active users of the dispute settlement system and many often do not have a direct interest in DSB agenda items. Larger countries and the most frequent users of the dispute system attend every meeting of the DSB, while smaller or not very active ones will send a representative when convenient. ${ }^{77}$ The majority of report statements have been made by the most active users of the dispute system, with the U.S. and the European Union (EU) (formerly EC) the most vocal in absolute terms (see Table 2). Among newer Members, those that participate in more disputes (either as a party or a third party) are slowly increasing their expression of views prior to report adoption. Examples include China, Vietnam and Saudi Arabia. Tellingly, only two Members that have never participated in any empaneled dispute (either as a party or a third party) have expressed a view prior to report adoption. ${ }^{78}$ Controlling for empaneled dispute participation reveals a different picture, with the less frequent users of the system relatively more vocal. For example, Malaysia is by far the most vocal Member relative to its participation as a party or third party. While frequent users of the system deliver more report statements in absolute terms, they are not necessarily more willing to express views when not directly involved in a dispute.

77. Interview 2.1, supra note 64 .

78. Prior to adoption of the Appellate Body and panel reports in United States-Section 211 Omnibus Appropriations Act of 1998 (WT/ DS176/AB/R; WT/DS176/R), Haiti issued a brief statement praising the Appellate Body's findings and supporting Cuba's position. See Dispute Settlement Body, Minutes of Meeting held on 1 February 2002, II 34, WT/DSB/M/1 19 (Mar. 6, 2002). Prior to adoption of the Appellate Body and panel reports in European Communities - Trade Description of Sardines (WT/DS231/AB/R; WT/DS231/R), Morocco expressed its frustration with its inability to defend its interests as a third-party and its resort to submission of an amicus curiae brief as an alternative procedure. See Dispute Settlement Body, Minutes of Meeting held on 23 October 2002, II 67-68, WT/DSB/M/134 (Jan. 29, 2003). 
Table 2: Member Participation within the

Dispute Settlement BodY**

\begin{tabular}{|c|c|c|c|}
\hline Rank & $\begin{array}{l}\text { Member } \\
\text { (Total Report } \\
\text { Statements) }\end{array}$ & $\begin{array}{l}\text { Member } \\
\text { (Report Statements } \\
\text { by Years Member) }\end{array}$ & $\begin{array}{l}\text { Member } \\
\text { (Report Statements by } \\
\text { Dispute Participation)* }\end{array}$ \\
\hline 1 & $\begin{array}{l}\text { USA } \\
(169)\end{array}$ & $\begin{array}{l}\text { USA } \\
(8.90)\end{array}$ & $\begin{array}{l}\text { Malaysia } \\
(6.5)\end{array}$ \\
\hline 2 & $\begin{array}{l}\text { European Union } \\
(150)\end{array}$ & $\begin{array}{l}\text { European Union } \\
(7.90)\end{array}$ & $\begin{array}{l}\text { Hong Kong, China } \\
(3.33)\end{array}$ \\
\hline 3 & $\begin{array}{l}\text { Canada } \\
(69)\end{array}$ & \begin{tabular}{|l|} 
Canada \\
$(3.63)$
\end{tabular} & $\begin{array}{l}\text { Antigua and Barbuda } \\
\text { (2) }\end{array}$ \\
\hline 4 & $\begin{array}{l}\text { Japan } \\
(57)\end{array}$ & $\begin{array}{l}\text { Japan } \\
(3)\end{array}$ & $\begin{array}{l}\text { Philippines } \\
(1.64)\end{array}$ \\
\hline 5 & $\begin{array}{l}\text { India } \\
(53)\end{array}$ & $\begin{array}{l}\text { India } \\
(2.79)\end{array}$ & $\begin{array}{l}\text { Egypt } \\
(1.25)\end{array}$ \\
\hline 6 & $\begin{array}{l}\text { Brazil } \\
(49)\end{array}$ & $\begin{array}{l}\text { Brazil } \\
(2.58)\end{array}$ & $\begin{array}{l}\text { Panama } \\
(1.14)\end{array}$ \\
\hline 7 & $\begin{array}{l}\text { Australia } \\
(46)\end{array}$ & $\begin{array}{l}\text { Australia } \\
(2.42)\end{array}$ & $\begin{array}{l}\text { Costa Rica } \\
(1.13)\end{array}$ \\
\hline 8 & $\begin{array}{l}\text { Mexico } \\
(44)\end{array}$ & $\begin{array}{l}\text { Mexico } \\
(2.32)\end{array}$ & $\begin{array}{l}\text { Indonesia } \\
\text { (1) }\end{array}$ \\
\hline 9 & $\begin{array}{l}\text { Hong Kong, China } \\
(40)\end{array}$ & $\begin{array}{l}\text { Hong Kong, China } \\
(2.11)\end{array}$ & $\begin{array}{l}\text { Cameroon } \\
\text { (1) }\end{array}$ \\
\hline 10 & $\begin{array}{l}\text { Republic of Korea } \\
(36)\end{array}$ & $\begin{array}{l}\text { China } \\
(1.92)\end{array}$ & $\begin{array}{l}\text { Hungary } \\
(1)\end{array}$ \\
\hline 11 & $\begin{array}{l}\text { Argentina } \\
(34)\end{array}$ & $\begin{array}{l}\text { Republic of Korea } \\
(1.90)\end{array}$ & $\begin{array}{l}\text { Poland } \\
\text { (1) }\end{array}$ \\
\hline 12 & $\begin{array}{l}\text { China } \\
\text { (25) }\end{array}$ & $\begin{array}{l}\text { Argentina } \\
(1.79)\end{array}$ & $\begin{array}{l}\text { Switzerland } \\
\text { (1) }\end{array}$ \\
\hline 13 & $\begin{array}{l}\text { Chile } \\
(24)\end{array}$ & $\begin{array}{l}\text { Chile } \\
(1.26)\end{array}$ & $\begin{array}{l}\text { Saint Lucia } \\
\text { (1) }\end{array}$ \\
\hline 14 & $\begin{array}{l}\text { Thailand } \\
(20)\end{array}$ & $\begin{array}{l}\text { Thailand } \\
(1.05)\end{array}$ & $\begin{array}{l}\text { Ecuador } \\
(0.94)\end{array}$ \\
\hline 15 & $\begin{array}{l}\text { Norway } \\
(19)\end{array}$ & $\begin{array}{l}\text { Norway } \\
\text { (1) }\end{array}$ & $\begin{array}{l}\text { USA } \\
(0.93) \\
\end{array}$ \\
\hline 16 & $\begin{array}{l}\text { Philippines } \\
\text { (18) }\end{array}$ & $\begin{array}{l}\text { Philippines } \\
(0.95)\end{array}$ & $\begin{array}{l}\text { European Union } \\
(0.90)\end{array}$ \\
\hline 17 & $\begin{array}{l}\text { Costa Rica } \\
(17)\end{array}$ & $\begin{array}{l}\text { Costa Rica } \\
(0.90)\end{array}$ & $\begin{array}{l}\text { Argentina } \\
(0.85)\end{array}$ \\
\hline 18 & $\begin{array}{l}\text { Ecuador } \\
(16)\end{array}$ & $\begin{array}{l}\text { Ecuador } \\
(0.89)\end{array}$ & $\begin{array}{l}\text { Chile } \\
(0.83)\end{array}$ \\
\hline
\end{tabular}




\begin{tabular}{|c|l|l|l|}
\hline 19 & $\begin{array}{l}\text { Malaysia } \\
(13)\end{array}$ & $\begin{array}{l}\text { Malaysia } \\
(0.68)\end{array}$ & $\begin{array}{l}\text { Canada } \\
(0.78)\end{array}$ \\
\hline 20 & $\begin{array}{l}\text { Guatemala } \\
(12)\end{array}$ & $\begin{array}{l}\text { Guatemala } \\
(0.63)\end{array}$ & $\begin{array}{l}\text { Cote d'Ivoire } \\
(0.75)\end{array}$ \\
\hline
\end{tabular}

*Rankings for Report Statements by Dispute Participation calculated by normalizing total report statements with the number of individual empaneled disputes in which a Member participated as a party or third-party.

**Source: Authors' dataset of all statements made within the WTO Dispute Settlement Body from 1995-2012. Minutes of DSB meetings obtained from the WTO's Documents Online system.

The subset of Members that have made at least two report statements differs considerably from the WTO membership as a whole, along a number of relevant characteristics (see Table $3)$. First, wealthier countries tend to express report views. The average Gross Domestic Product (GDP) per capita for speaking Members is nearly twice as large as the average for the membership as a whole. ${ }^{79}$ Second, the average share of international trade in GDP for vocal governments is slightly lower (7.32 per cent) than for the membership as a whole. This measure proxies the importance of international trade within countries, with international trade typically more important for small countries with lower levels of economic self-sufficiency. Third, larger countries are disproportionately expressing views, with the average total population of speaking Members 2.5 times that of the membership as a whole. However, vocal governments are broadly representative of the total membership in terms of level of urbanization. Fourth, more powerful countries tend to express report views more frequently, with average military expenditure and size for vocal Members over twice that of the averages for the membership as a whole. ${ }^{80}$ Finally, the average level of democracy for speak-

79. Panel data for GDP per capita (current USD), international trade as a percentage of GDP, total population and urban population (percent of total population) obtained from the World Bank's World Development Indicators databank, available at http://databank.worldbank.org/ (last visited Mar. 8, 2014).

80. Panel data for Military Expenditure and Military Personnel obtained from the Correlates of War National Military Capabilities (v4.0) data set, accessed 8 March 2014. J. David Singer, Reconstructing the Correlates of War Dataset on Material Capabilities of States, 14 INT'L INTERACTIONS 115 (1988) (describing the content, sources and coding of variables contained within the data set). 
ing governments is almost twice that of the membership as a whole. ${ }^{81}$ These differences clearly demonstrate that the countries making report statements are not representative of the entire WTO membership in terms of wealth, trade dependency, size, power or degree of domestic democratic governance.

Table 3: Representativeness of Members that EXPRESS REPORT VIEWS**

\begin{tabular}{|l|l|l|l|}
\hline & $\begin{array}{l}\text { Members that } \\
\text { have made }>1 \\
\text { report statement }\end{array}$ & $\begin{array}{l}\text { Entire WTO } \\
\text { Membership }\end{array}$ & $\begin{array}{l}\text { Difference in } \\
\text { Mean }\end{array}$ \\
\hline $\begin{array}{l}\text { GDP per capita } \\
\text { (current USD) }\end{array}$ & $26,864.60$ & $13,259.88$ & $+13,604.72$ \\
\hline $\begin{array}{l}\text { Share of } \\
\text { International } \\
\text { Trade in GDP (\%) }\end{array}$ & 79.56 & 86.88 & -7.32 \\
\hline Total Population & $115,310,578.3$ & $46,251,507.6$ & $+69,059,070.7$ \\
\hline $\begin{array}{l}\text { Urban Population } \\
\text { (\% of total) }\end{array}$ & 62.46 & 51.66 & +10.8 \\
\hline $\begin{array}{l}\text { Military } \\
\text { Expenditure } \\
\text { (thousands of } \\
\text { current USD) }\end{array}$ & $19,630,728.4$ & $7,355,902.92$ & $+12,274,825.48$ \\
\hline $\begin{array}{l}\text { Military Personnel } \\
\text { (thousands) }\end{array}$ & 262.76 & 112.00 & 150.76 \\
\hline Polity IV score & 6.199 & 3.350 & +2.849 \\
\hline
\end{tabular}

**Data Sources: Data for GDP per capita (current USD), international trade as a percentage of GDP, total population, and urban population (percentage of total population) obtained from the World Bank's World Development Indicators databank, available at: http://databank.worldbank.org. Data for Military Expenditure and Military Personnel obtained from the Correlates of War National Military Capabilities (v4.0) data set, available at: www.corre latesofwar.org. Polity IV data obtained from: www.systemicpeace.org/polity/ polity4.htm.

Note: Averages calculated for all Members during years as a WTO Member only (where data available). Averages calculated excluding all EU member states. For the European Union, averages for GDP per capita, total population, military expenditure and military personnel calculated by summing EU

81. Panel data for level of democracy obtained from the Polity IV Project. Monty G. Marshall, Ted Robert Gurr \& Keith Jaggers, Polity IV Project: Political Regime Characteristics and Transitions, 1800-2012 (June 6, 2014), http://www .systemicpeace.org/polity/polity4.htm. 
member state averages; EU averages for share of international trade in GDP, urban population and Polity IV score calculated by averaging EU members states averages.

\section{Content of Report Statements}

Parties have extensive opportunities to develop their legal arguments within written and oral submissions and during the interim review stage, yet it is 'almost customary' for parties to make a statement prior to report adoption. ${ }^{82}$ To date all have done so, with one exception. ${ }^{83}$ Parties to a dispute have made almost half (46.5 per cent) of all report statements, although third parties also regularly express views (34.1 per cent of all report statements). Third party expression of views has decreased slightly from the early years of the WTO's dispute settlement system, a trend that some Member delegates have noted, ${ }^{84}$ but the difference is not substantial. Although the average number of third parties per dispute has grown steadily over the years, the percentage of third parties to a dispute expressing views has not declined significantly (see Figure 1). Third parties are more willing to express views on $A B$ and Article 21.5 compliance decisions than on panel reports, though statements on $\mathrm{AB}$ reports typically discuss the panel findings as well. Members not party or third party (the "non-parties") to a dispute have made 19.4 per cent of total report statements, and express views primarily on decisions of the $A B$ and not panel or Article 21.5 decisions.

\footnotetext{
82. Interview 1.3, supra note 76.

83. Prior to adoption of the Appellate Body and panel reports in Mexico - Taxes on Soft Drinks WT/DS308/AB/R (March 6, 2006) and WT/DS308/ $\mathrm{R}$ (March 6, 2006), Mexico did not express a view. See Dispute Settlement Body, Minutes of Meeting held on 24 March 2006, II 1-11, WT/DSB/M/208 (April 28, 2006) (containing minutes of the DSB meeting in which the reports in Mexico - Taxes on Soft Drinks were adopted by the DSB, during which only the United States, a party to the dispute, and the European Communities, a third party made statements and Mexico did not make a statement prior to report adoption).
}

84. Interview 5.5, supra note 62. 


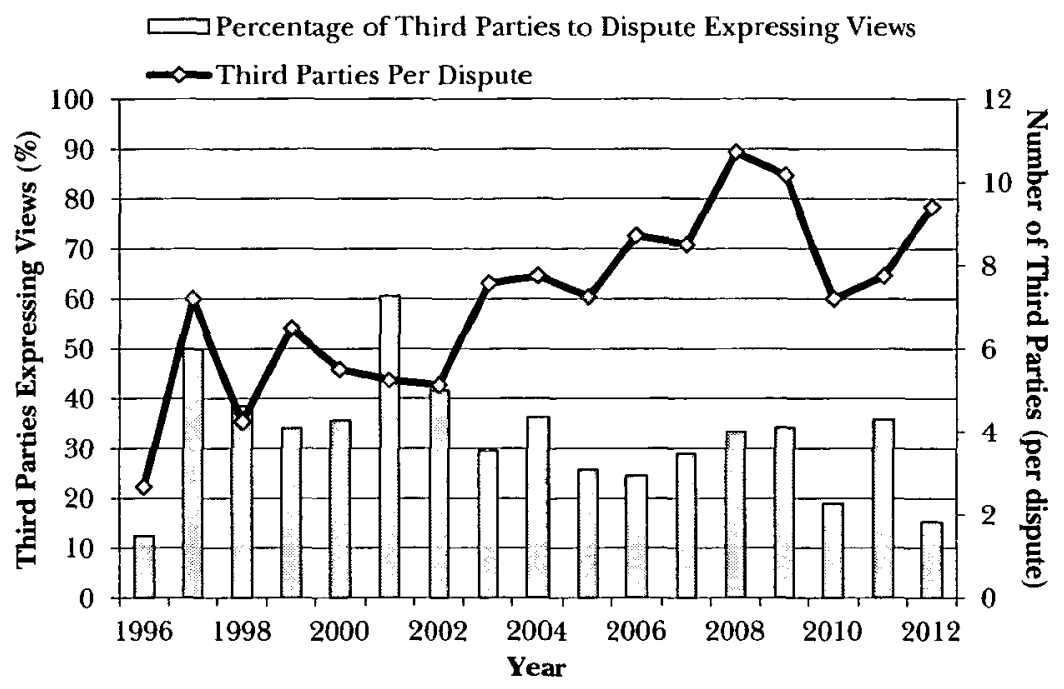

Figure 1: Third Party Expression of Report Views

Source: Authors' dataset of all statements made within the WTO Dispute Settlement Body from 1995-2012. Minutes of DSB meetings obtained from the WTO's Documents Online system.

Overall, third parties and non-parties are much more cautious about expressing views on the record. Some worry that the statement may be "used against [them] at a later stage." 85 For this reason, many typically reserve report statements for procedural and systemic issues. ${ }^{86} \mathrm{~A}$ number of government representatives indicated that statements by third or non-parties could be particularly valuable in terms of providing "more neutral feedback to the Secretariat." ${ }^{7}$ As discussed further below, the ability to express a substantive view on a report requires the legal capacity and resources necessary to analyze its systemic legal implications. Participation as a third party may be one method to develop such capacity, ${ }^{88}$ and not surpris-

85. Interview 1.1, supra note 73 ; Interview 1.3, supra note 76.

86. Interview 1.3, supra note 76; Interview 2.4, supra note 73; Interview 3.2, in Geneva, Switz. (Jan. 15, 2014).

87. Interview 1.1, supra note 73.

88. See Christina L. Davis \& Sarah Blodgett Bermeo, Who Files? Developing Country Participation in GATT/WTO Adjudication, 71 J. Pol. 1033, 1036-38 (2009) (discussing three countries that have demonstrated how experience in litigation promotes learning and reduces startup costs for subsequent litigation); Interview 1.4, in Geneva, Switz. (Jan. 13, 2014). 
ingly countries that regularly participate as third parties are also more likely to express report views in general. Only three governments have issued report statements without ever having participated as a third party in a dispute: Antigua and Barbuda, Haiti, and Morocco ${ }^{89}$ In addition, the average number of report statements for Members that have participated in more than ten disputes is more than seven times that for Members having participated in less than ten.

The substance of a report statement understandably varies according to whether the Member was a party to the case, had a direct economic interest in the dispute, or whether the report addressed issues with potential implications for future disputes. Report views can roughly be placed into three categories: (1) those that focus on the merits of the report findings in that particular dispute; 90 (2) those that note findings, interpretations or procedural decisions adopted within a report and highlight their implications for future disputes, the system as a whole or broader interpretive consistency; ${ }^{91}$ and (3) those that merely take note of an interpretation or finding, in order to flag it as an issue deserving further consideration, without adopting a substantive view. ${ }^{92}$ A Member might express all

89. Morocco's statement was related to a dispute in which it had attempted to participate as a third party but had missed the deadline to do so. Dispute Settlement Body, Minutes of Meeting held on 23 October 2002, II 67-68, WT/DSB/M/134 (Jan. 29, 2003). Antigua and Barbuda's statements related to a dispute in which it was the complainant.

90. See, e.g., Dispute Settlement Body, Minutes of Meeting held on $15 \mathrm{July}$ 2011, II 2-4, WT/DSB/M299 (Sept. 1, 2011) (expressing support of the Philippines, a party to the Thailand-Cigarettes (Philippines) (WT/DS371/ $\mathrm{AB} / \mathrm{R} ; \mathrm{WT} / \mathrm{DS371/R}$ ) dispute, with the Reports and emphasizing that the Reports had given clear guidance as to the contents of the disputed rules).

91. See, e.g., Dispute Settlement Body, Minutes of Meeting held on 23 March 2012, I 76, WT/DSB/M/313 (May 29, 2012) (expressing views of Canada (a third party to US-Large Civil Aircraft (Second Complaint) (WT/DS353/AB/R; WT/DS353/R) dispute) on two interpretive issues with systemic implications found within the Reports: the causal analysis required to support a panel finding that subsidies caused serious prejudice and the scope of the specificity analysis under art 2.1 (a) of the SCM Agreement).

92. See, e.g., Dispute Settlement Body, Minutes of Meeting held on 6 November 1998, at 13, WT/DSB/M/50 (Dec. 14, 1998) (noting prior to adoption of the Appellate Body and panel reports in $U S-S h r i m p s$ (WT/DS58/AB/R; WT/DS58/R) Australia's recognition that " $[\mathrm{t}]$ he Appellate Body's finding had pointed to some important aspects of these tests which deserved further consideration"). 
three types of views within one statement, though parties largely focus on the first category while third and non-parties tend to highlight the second. Parties to a dispute typically reiterate legal arguments made within their submissions and highlight particular report findings or procedural aspects with which they strongly agree or disagree. Third and non-parties generally limit their comments to specific findings or procedural issues that raise systemic concerns or that might affect their interests in the future. For the most part, these statements are shorter than those of parties, though there are exceptions.

Third parties are more vocal regarding politically or economically sensitive disputes. For instance, in the EC-Bananas III dispute, a number of third parties had direct economic interests in its resolution and were correspondingly vocal during report adoption. ${ }^{93}$ Adoption of the panel report in US-Section 301 Trade Act, ${ }^{94}$ regarding the controversial U.S. legislation permitting unilateral authorization of trade sanctions, generated the largest number of third party statements on any one report to date (twelve in total) and a significant number of non-party statements (six in total) ${ }^{95}$

Reports for which non-parties express views are those that raise systemic or procedural issues of concern to the membership as a whole. For example, prior to the adoption of the $A B$ report in US-Lead and Bismuth II, ${ }^{96}$ sixteen non-party governments expressed views (the largest number of non-party statements made on a report to date). All sixteen of these state-

93. For example, prior to the adoption of the Appellate Body and Panel Reports in European Communities-Regime for the Importation, Sale and Distribution of Bananas (WT/DS27/AB/R; WT/DS27/R/ECU; WT/DS27/R/GTM; WT/DS27/R/HND; WT/DS27/R/MEX; WT/DS27/R/USA), eight third parties and two non-parties issued statements. Dispute Settlement Body, Minutes of Meeting held on 25 September 1997, at 14-25, WT/DSB/M/37 (Nov. 4, 1997).

94. Panel Report, United States-Sections 301-310 of the Trade Act 1974, WT/DS152/R (Dec. 22, 1999).

95. Dispute Settlement Body, Minutes of the Meeting held on 27 January 2000, II 10-20, WT/DSB/M/74 (Feb. 22, 2000).

96. Appellate Body Report, United States-Imposition of Countervailing Duties on Certain Hot-Rolled Lead and Bismuth Carbon Steel Products Originating in the United Kingdom, WT/DS138/AB/R (May 10, 2000). 
ments discussed the AB's decision to accept and consider amicus curiae submissions in that dispute. ${ }^{97}$

The tone of views expressed understandably varies across reports, with some representatives noting that because panel reports do not have the same authority as those issued by the $\mathrm{AB}$, Members are slightly more critical towards the former. For third parties or non-parties in particular, expression of views might represent the only chance "to make a statement and voice criticism against a report." 98 The tone of views also appears to vary across Members. Some interviewees noted apparent differences in tone between the EU and the U.S. in particular, in that the U.S. is more willing to voice overt criticism of $\mathrm{AB}$ interpretations while the $\mathrm{EU}$ exhibits greater reluctance to express strong disapproval. ${ }^{99} \mathrm{~A}$ key word analysis of EU and U.S. report statements tentatively supports this observation, with the EU expressing relatively more "satisfaction" within its statements than the U.S. ${ }^{100}$ Some interviewees suggested that differences in Members' willingness to express overt disapproval within report statements relates to cultural differences and different attitudes about the proper role of international adjudicative bodies. ${ }^{101}$ While the personality of the individual delivering the oral statement may partly impact perceived tone, the influence of individual characteristics is likely minimal, as most of these statements are drafted prior to the DSB meeting and must be approved by the Member's capital.

\section{E. Current Use of Report Statements to Communicate with the DSM}

To a certain extent, Members already use report statements to provide interpretive feedback to the WTO's adjudicative bodies. A few smaller or less active delegations firmly

97. Dispute Settlement Body, Minutes of Meeting held on 7 June 2000, WT/ $\mathrm{DSB} / \mathrm{M} / 83$ (July 7,2000 ) (all statements during the DSB meeting concerned the report in US-Lead and Bismuth II).

98. Interview 1.3, supra note 76 .

99. Id:; Interview 2.4, supra note 73 .

100. Using the program WordSmith (Scott, M., 2012, WordSmith Tools version 6, Stroud: Lexical Analysis Software) this analysis found that the EU employed the term "satisfaction" within statements more often than would be expected by chance in comparison with U.S. report statements.

101. Interview 2.2, in Geneva, Switz. (Jan. 14, 2014); Interview 2.3, in Geneva, Switz. (Jan. 14, 2014). 
averred that the Secretariat or $A B$ members were not the intended audiences of such statements, ${ }^{102}$ but a number of representatives indicated that the primary intended audience for report statements is the system as a whole (the Legal Affairs Division of the Secretariat, panelists, the $A B$, and the Appellate Body Secretariat). The purpose of these statements is to place on the official record a government's views on legal interpretations or procedural decisions. ${ }^{103}$ Some representatives noted that report statements can "pass a message" to the Secretariat or panelists in future disputes, particularly with respect to procedural issues. ${ }^{104}$

A couple of the most active Members-particularly those that stressed the independence of the $A B$ and the authoritativeness of their reports-- did not see any value in regularly expressing criticism of a report's reasoning or findings, and indicated they only voice a critical statement to signal that the issue raised is of considerable importance. ${ }^{105}$ Almost all representatives independently employed the language of "sending messages" to the AB or Secretariat, emphasizing that report statements "do have a systemic value for the legitimacy of the institution," 106 though the strength of the signal might depend on how many Members expressed or supported the same view. ${ }^{107}$ As one representative phrased it:

If [the panel or the Appellate Body] makes a decision that was too daring, and nobody says anything, they will think they got it right. But if twenty countries, or fifteen, or even ten-but in very strong words-come and criticize, and go in to the legal details, [the Secretariat or the Appellate Body members] will discuss it internally. Because perhaps they got it right legally, but politically they may have gotten it wrong. ${ }^{108}$

A number of representatives also believe that the Secretariat's Legal Affairs Division and the Appellate Body Secretariat

102. Interview 3.2, supra note 86; Interview 4.5, in Geneva, Switz. (Jan. 16, 2014).

103. Interview 3.4, in Geneva, Switz. (Jan. 15, 2014); Interview 5.5, supra note 62; Interview 5.6, in Geneva, Switz. (Jan. 17, 2014).

104. Interview 1.3, supra note 76; Interview 5.5, supra note 62.

105. Interview 1.3, supra note 76; Interview 2.2, supra note 101.

106. Interview 2.4 , supra note 73 .

107. Interview 5.5 , supra note 62 .

108. Id. 
are paying attention to their report views. ${ }^{109}$ Representatives from the Legal Affairs Division of the Secretariat and the Appellate Body Secretariat sit in on DSB meetings, and interviews with WTO officials confirmed that these two bodies pay particular attention to systemic and procedural issues raised by Members in the context of report adoption. ${ }^{10}$ As almost all interviewees emphasized, whether particular views actually influence or play a decisive role in subsequent decisions is a separate question. If it does occur at all, such influence is likely "very subtle" due to the independent authority of the WTO's adjudicative bodies. ${ }^{111}$

A search of all adopted reports to date indicates that panels or the $A B$ have never cited statements made prior to report adoption, even though they often cite the minutes of DSB meetings in relation to the procedural history of a dispute or as indirect evidence of a panel's terms of reference. ${ }^{112} \mathrm{We}$ are not arguing that the panels or $\mathrm{AB}$ should begin to cite expression of views within their reports, but rather that they should look to such statements as a source of information about Members' interpretive preferences.

This section provided considerable evidence that expression of report views does provide a systematic mechanism through which the WTO membership's interpretive preferences could be made known to the Organization's adjudicative bodies. As described above, the use of expression of views prior to report adoption to date is limited in important respects. The subset of governments that regularly expresses views is not representative of the distribution of wealth, trade dependency, size, power or degree of domestic democratic governance across the membership as a whole. For these reasons, we propose that a broader range of Members actively for-

109. Interview 2.4, supra note 73; Interview 5.1, in Geneva, Switz. (Jan. 17, 2014); Interview 5.2, in Geneva, Switz. (Jan. 17, 2014); Interview 5.5, supra note 62 .

110. Interview 2.3, supra note 101.

111. Interview 4.3, in Geneva, Switz. (Jan. 16, 2014).

112. For example, the panel and the Appellate Body cited extensively to DSB meeting minutes in the context of US-Large Civil Aircraft (Second Complaint), in order to establish the procedural history regarding requests for Annex V procedures under the SCM Agreement. See Appellate Body Report, United States-Measures Affecting Trade in Large Civil Aircraft (Second Complaint), II $8,85,388,482,538-39,541$, WT/DS353/AB/R (Mar. 12, 2012). 
mulate and express report views, either individually or jointly. The following section further elaborates the normative justification for this proposal and outlines how it would work in practice, addressing potential obstacles and limitations to its implementation.

\section{Deliberative Engagement Through EXPRESSION OF VIEWS}

\section{A. The Duty of Deliberative Engagement in the WTO}

As recently outlined by Ethan J. Leib, David L. Ponet, and Michael Serota, a fiduciary theory of judging is one that attempts to addresses the diverse- and oftentimes conflictingresponsibilities of judges. ${ }^{13}$ It views the judicial role in terms of a fiduciary relationship, which is characterized by one actor (the fiduciary) holding "discretionary power over the practical interests of another (the beneficiary)."114 In the domestic context, citizens represent the beneficiaries of courts to which they delegate authority over their legal interests. In the international context, a court's set of beneficiaries differs across institutions. As mentioned previously, in the context of the "member-driven" WTO, Members represent the primary constituents and beneficiaries that have delegated authority over their legal interests to the DSM. ${ }^{115}$

Under a fiduciary theory, judges are under an obligation to engage in deliberative engagement with their beneficiaries. Skeptics might argue that such engagement in the context of the WTO could endanger the independence and impartiality of the DSM's decision-makers. However, the obligation to en-

113. Leib, Ponet \& Serota, supra note 17 , at 700.

114. Paul B. Miller, A Theory of Fiduciary Liability, 56 McGrLl L.J. 235, 262 (2011).

115. While industry organizations, corporations, consumer interest groups, and individual citizens may all be affected by trade measures and panel and Appellate Body reports and thus could be regarded as beneficiaries, their views will often be reflected within and through the expressed views of WTO Members, either in proceedings or through statements in meetings of the political bodies of the Organization. The DSU itself indirectly supports the claim that the membership as a whole, in contrast to the narrow subset of active participants in disputes, constitutes the beneficiaries. See DSU art. 17(3) (establishing that "the Appellate Body membership shall be broadly representative of the WTO," presumably so that the AB will render decisions that reflect the broader membership). 
gage in deliberative engagement does not require that the DSM always conform its decisions to the preferences of its beneficiaries. Rather, it stipulates that the DSM should consider these preferences and provide reasoned decisions that in some way speak to these views or interests. Considerable evidence suggests that the DSM already pays attention to what is said within DSB meetings. The current problem is that these views rarely represent those of the membership as a whole. The duty of deliberative engagement also needs to be understood in relation to judges' other fiduciary obligations, namely care and loyalty. While care is meant to ensure reason-based decisions, the loyalty obligation emphasizes the importance of impartiality, which is the "cornerstone" of a judge's ethical commitment. ${ }^{116}$ Considered in tandem with judges' other obligations, the duty of deliberative engagement serves to strengthen the DSM in fulfilling its delegated role in an impartial manner.

The duty of deliberative engagement may further be seen in relation to the customary rules of interpretation on which DSU Article 3(2) stipulates the DSM should rely. Article 32 of the Vienna Convention on the Law of Treaties ${ }^{117}$ directs the DSM to look to sources that can shed light on Members' "intention when they accepted a given provision and their understanding as to its content." 118 As a rule of interpretation it encourages the DSM to fulfill its duty of deliberative engagement by actively seeking to uncover beneficiary preferences. ${ }^{119}$ In a similar fashion, report statements provide the DSM with sup-

116. See Leib, Ponet \& Serota, supra note 17, at 731 (noting that "judicial loyalty and impartiality is the cornerstone of the ethical commitment of judges, both historically and in the contemporary ethical rules governing judges"); Erik Voeten, The Impartiality of International Judges: Evidence from the European Court of Human Rights, 102 Am. PoL. Sci. Rev. 417, 417 (2008) (discussing a growing scholarly consensus that impartiality is fundamental for effective adjudication in international dispute settlement). The WTO similarly emphasizes this obligation within the Working Procedures for Appellate Review, Annex II, Rules of Conduct for the DSU. Appellate Body Report, Working Procedures for Appellate Review, WT/AB/WP/6 (Aug. 16, 2010).

117. Vienna Convention on the Law of Treaties, May 23, 1969, 1155 U.N.T.S. 331.

118. Tarcisio Gazzini, Can Authoritative Interpretations Under Article IX:2 of the Agreement Establishing the WTO Modify the Rights and Obligations of Members?, 57 INT'ı. \& Comp. L. Q. 169, 178 (2008).

119. Id. 
plementary information regarding current preferences or understandings of ambiguous provisions.

While the WTO Agreement strengthened the independence of the DSM, by insulating it from the direct Member control exercised under the GATT, it simultaneously encouraged a type of deliberative engagement through interpretive feedback, by creating the two mechanisms of legislative response discussed previously: authoritative interpretations and amendments. Due to the practice of consensus decision-making within the WTO, governments have not been able to make effective use of the mechanism of authoritative interpretation in particular, depriving the DSM of a critical source of information regarding interpretive preferences.

Compounding this imbalance, informal precedent within the dispute settlement system enables the first movers-active users of the WTO's system since its inception-to delimit the range of preferred interpretations actively considered by the DSM. As parties to the dispute, the most active users not only possess numerous opportunities to present their legal arguments during the course of proceedings, in practice they also dominate statements made in the context of subsequent report adoption. Because the majority of views reaching the DSM represent only a minority of views potentially held by the WTO membership as a whole, the panels and AB are forced to operate in an environment of incomplete information regarding Members' interpretive preferences, biased towards a powerful minority.

A strategy of majoritarian activism-issuing judicial interpretations that a majority of (but not necessarily all) Members might be expected to adopt independently-represents a form of deliberative engagement that arguably helps international courts manage increased judicialization and the legitimacy problems associated with judicial lawmaking. ${ }^{120}$ While panels and the $\mathrm{AB}$ do sometimes adopt a strategy of majoritarian activism by assessing Article XX GATT defenses against policy outcomes on which a majority of countries would agree, this only occurs in a small number of disputes. ${ }^{121}$ Even if the WTO $\mathrm{AB}$ has occasionally interpreted the law in "ways that were un-

120. Sweet \& Brunell, supra note 12 , at 64 .

121. Id. at 83-85. Sweet \& Brunell examined all panel and $\mathrm{AB}$ reports that addressed the respondent government's defensive claims under art. XX 
wanted by powerful actors," 122 the fact that it consistently and disproportionately receives feedback from a subset of Members suggests that their views inevitably inform jurisprudential developments. In this respect, the DSM is currently unable to pursue deliberative engagement through anything but a strategy of minority activism, a clearly questionable development.

\section{B. Improving on Current Practices}

Given that governments likely will not begin to employ authoritative interpretations, they should increase their use of expression of report views within DSB meetings as a functional substitute. An increase in the proportion of Members making statements has the potential to address the current imbalance in the feedback received by the DSM. In particular, governments should more actively engage in an iterative albeit indirect form of "dialogue" when a report raises issues with potentially systemic implications or procedural matters. A greater and more representative subset of countries engaging in such a dialogue would benefit both the adjudicative bodies and the membership as a whole, and help strengthen the fiduciary relationship.

To address the issue of representativeness, a greater number of third and non-parties should seek to place their views on the record. Increasing the number of third and non-party report views would also lead to a broader focus within statements, as governments not affected directly by a report's findings may focus more on system-wide implications. Presently, report views tend to reiterate legal positions pleaded during the dispute, with the winning party typically supporting the report and the losing party voicing unequivocal criticism, sometimes moving from criticism of a specific dispute finding to challenges to the DSM's authority. ${ }^{123}$ Third or non-parties, with a relatively more modest stake in the dispute's specific outcome, have fewer incentives to express narrow views and

(GATT) or art. XV (General Agreement on Trade in Services) between 1995 and 2011 , for a total of 22 reports.

122. Alter, Agents or Tristees, supra note 14, at 52.

123. Authors' dataset available on request. See Cosette D. Creamer \& Zuzanna Godzimirska, (De)Legitimation at the WTO Dispute Settlement Mechanism, 49 VAND. J. TRANSNAT'L L. (2016) (describing the content, tone, and sentiment of statements made prior to report adoption). 
for this reason may provide more constructive guidance on Members' interpretive preferences.

\section{Potential Limitations and Obstacles}

Increasing the number of views expressed would increase the length of DSB meetings and place additional resource burdens on many countries, giving rise to a potential tradeoff between widespread participation and efficiency. ${ }^{124}$ To address this, Members could establish a practice of coordinating interpretive preferences prior to DSB meetings and employing joint statements whenever feasible. Within GC meetings, governments often issue joint statements that express views on behalf of others (10.6 per cent of all statements made within the General Council between 1995 and 2012). For many of these statements, representatives speak on behalf of WTO coalitions or groups formed in the context of negotiations, based on shared positions or interests. ${ }^{125}$ Compared to GC meetings, however, representatives employ joint statements much less frequently within DSB meetings $(0.8$ per cent of all statements made within the DSB between 1995 and 2012). ${ }^{126}$

One reason for this difference may be that the DSB is inherently more individualistic than the GC, as it focuses on specific disputes between two (or more) countries, and thus is not susceptible to coalitional or group statements. Members might not want to expressly take sides in a dispute by voicing support for an interpretation that may have benefited one party to the detriment of the other. For this reason, the idea of interpretive coalitions in the DSB could be diplomatically or politically untenable to certain governments. However, the practice of joint statements is still transposable to the DSB, where groups of countries could come to share common interpretive preferences. For example, common interpretive preferences emerged during discussion of the amicus curiae question

124. See Schaffer \&e Trachtman, supra note 8, at 17.

125. For an overview of coalition groups within negotiations, see WTO, Groups in the negotiations http://www.wto.org/english/tratop_e/dda_e/nego tiating_groups_e.htm (last visited Jan. 23, 2016).

126. Between 1995 and 2012, Members have issued 74 joint statements within DSB meetings, many of which expressed concern about another Member's noncompliance with a DSB ruling. Dataset available on request. 
within DSB and GC meetings in $2000^{127}$ and following Honduras' second panel request in the Australia-Plain Packaging dispute. ${ }^{128}$ The practice of forming coalitions within the DSB also exists in the context of DSU review negotiations, and third parties do occasionally present joint written submissions or oral statements. ${ }^{129}$ The practice of joint interpretive statements

127. On 7 November 2000 the Appellate Body division hearing the appeal in EC-Measures affecting asbestos and asbestos-containing products adopted an additional procedure to deal with amicus curiae briefs from persons other than the parties or third parties to the dispute. European Communities-Measures affecting asbestos and asbestos-containing products, Communication from the Appellate Body, WT/DS135/9 (Nov. 8, 2000). During a DSB meeting, Members were informed that a special GC meeting had been convened at the request of Egypt, on behalf of the Informal Group of Developing Countries, to discuss the Appellate Body's procedure. Dispute Settlement Body, Minutes of Meeting held on 17 November 2000, 11 126-37, WT/DSB/M/92 (Jan. 15, 2001). During both meetings, and the GC meeting in particular, most Members making a statement expressed the view that the approach of the Appellate Body was inconsistent with the DSU provisions. Some representatives even specifically referred to other Members' statements expressing explicit support for their view on the matter. See, e.g., statement by the representative of Brazil, stating that he "... supported the statement made by Egypt on behalf of the Informal Group of Developing Countries." General Council, Minutes of Meeting held on 22 November 2000, I 41, WT/GC/M/60 (Jan. 23, 2001 ).

128. On 25 September 2013 , Honduras submitted a second panel request ten months after its original panel request. Australia questioned whether this could be considered the second panel request, subject to automaticity, given the lengthy period of time between requests. Members engaged in a protracted debate within the DSB, with 26 Members making a statement. See Dispute Settlement Body, Minutes of Meeting held on 25 September 2013, II 4.1-4.68, WT/DSB/M/337 (Jan. 13, 2014). While not occurring within the context of report adoption, this discussion does demonstrate the existence of common interpretive preferences and Members' willingness to express views even if to the detriment of one of the disputing parties.

129. For example, the delegations of Brazil, Paraguay, and Uruguay decided to present a joint third-party statement in Argentina-Footwear. See Panel Report, Argentina-Safeguard Measures on Imports of Footwear, II 6.1-6.12, WT/DS121/R (June 25, 1999). In EC-Tariff Preferences, Bolivia, Colombia, Ecuador, Peru, and Venezuela presented a joint third-party submission as the Andean Community, as did the Central American countries of El Salvador, Guatemala, Honduras, and Nicaragua. See Panel Report, European Communities - Conditions for the Cranting of Tariff Preferences to Developing Countries, II 5.1-5.42, 5.63-5.78, WT/DS246/R (Dec. 1, 2003). In ECSugar Subsidies, the African, Caribbean, and Pacific (ACP) Sugar Supplying States (Barbados, Belize, Fiji, Guyana, Côte d'Ivoire, Jamaica, Kenya, Madagascar, Malawi, Mauritius, St. Kitts and Nevis, Swaziland, Tanzania, and Trinidad and Tobago) presented both a joint written submission and a joint oral 
within the DSB is thus possible and would help mitigate the potential tradeoff between widespread participation and efficiency. More critically, joint statements would permit smaller delegations-that often cannot attend every DSB meeting-to place their interpretive views on the record, as a statement could be circulated to and agreed upon by the relevant Members beforehand.

A potential obstacle to increasing the number and representativeness of report views stems from Members' hesitancy to put their views on the record, for fear of taking sides or because of uncertain implications for potential future disputes. This could be addressed if governments understood that the purpose of these statements would not be to adopt a position on the substantive dispute resolved within the report, but rather to consider implications for the jurisprudential development of the system as a whole. ${ }^{130}$ They should also understand that they would not be formally bound by their interpretive view in the future, even if placed on the record of a DSB meeting. It is understandable that interpretive preferences of countries may change over time. Given the relative frequency with which reports are adopted, compared to the relatively static mechanism of authoritative interpretations this mechanism permits Members to update and change their interpretive positions as their preferences change.

A more serious concern is that many countries, particularly smaller delegations and non-users of the dispute settlement system, simply do not have any interest in expressing a view prior to report adoption. However, a number of less active and smaller delegations indicated that this lack of interest stemmed largely from lack of expertise and knowledge about the jurisprudential implications of reports. ${ }^{131}$ A number of

presentation. See Panel Report, European Communities-Export Subsidies on Sugar, II 5.1-5.12, WT/DS265/R, WT/DS266/R, WT/DS283/R (Oct. 15, 2004).

130. Members already express views within DSB meetings that might not always be well received by others, yet they view this as acceptable so long as they inform those with whom they disagree beforehand, according to, inter alia, one of the Member representatives interviewed. Interview 5.6, supra note 103 .

131. Interview 4.8, in Geneva, Switz. (Jan. 16, 2014). See also Marc L. Busch, Eric Reinhardt \& Gregory Shaffer, Does Legal Capacity Matter? A Survey of WTO Members, 8 WORLd Trade Rev. 559 (finding that legal capacity has 
Members view the ability to actively express constructive views as requiring a level of expertise and resources that many do not possess currently, a limitation faced by both developing and smaller developed countries. ${ }^{132}$ Panel and $\mathrm{AB}$ reports often span several hundreds of pages and can address fairly complex and technical legal, economic and even scientific issues.

In order to address this obstacle, more resourced Members could take the lead in organizing working groups to explain and discuss interpretive issues raised by a report. Similar to how Members currently lobby for support on other issues within the DSB, ${ }^{133}$ one or more Members could hold informal meetings to help inform smaller, less-resourced Members about their views on particular interpretations, highlighting systemic implications. This would, at the very least, allow smaller Members to formulate slightly more informed positions regarding a report's interpretations and implications. Even if these meetings did not lead to a lengthy or in-depth statement, they would facilitate the ability of many Members to put on the record support for or disagreement with clarifications or interpretations voiced by other Members. While having more active or resourced Members take the lead in organizing these working groups could lead to the same unrepresentative outcome-with DSB statements only representing these parties' positions-other resourced Members with different interpretive preferences would be incentivized to convene their own working groups. Although there is a limited amount of time between the circulation and adoption of a report, Members could attend more than one working group. ${ }^{134}$ Ulti-

the potential to help Members in all aspects of WTO dispute settlement); Joseph A. Conti, Leaming to Dispute: Repeat Participation, Expertise, and Reputation at the World Trade Organization, 35 LAW \& SOC. INQUiky 625, 626-627 (2010) (emphasizing the importance of practical familiarity with legal processes to repeat players in dispute resolution in general, and the WTO more specifically); Davis \& Bermeo, supra note 88, at 1047 (finding that the lack of experience may be an important constraint for participation in international legal bodies).

132. Interview 3.1, in Geneva, Switz. (Jan. 15, 2014); Interview 4.2, in Geneva, Switz. (Jan. 16, 2014; Interview 4.5, supra note 102; Interview 4.8, supra note 131 .

133. Interview 1.1, supra note 73; Interview 4.8, supra note 131.

134. The DSU provides strict timelines for adoption of a report by the DSB following its circulation. For an Appellate Body Report, for example, 
mately each Member would retain the right to formulate its own position, or at the very least obtain a more informed view when expressing support for other Members' views.

Another option or supplement to such Member-driven working groups would be to establish neutral support bodies to provide jurisprudential overviews and analyses of reports for all Members, similar to U.S. state legislatures' reliance on research agencies to monitor judicial interpretations of statutes. ${ }^{135}$ Such a support function could be provided by nongovernmental organizations or law firms in Geneva with trade or WTO law expertise, many of which already hold workshops on particularly important dispute reports. ${ }^{136}$ Although such workshops play a critical role in improving Members' understanding of the DSM's jurisprudence, they typically occur after report adoption and are often restricted to selected Members. ${ }^{137}$ If convened prior to report adoption, these meetings could facilitate the expression of views by smaller or lessresourced Members within DSB meetings. Alternatively, Members could appoint a group of Secretariat officials within the Legal Affairs Division with the exclusive job of providing neutral summaries of key interpretive developments within reports, thereby fulfilling a role similar to that of legislative research agencies in the domestic context. Although the Legal Affairs Division is willing to provide legal research and analysis to individual Members, this is done only if so requested. For smaller delegations in particular, requesting information about interpretations contained within reports simply has lower priority than many other WTO responsibilities. However, if the Secretariat institutionalized the systematic provision of (necessarily brief) report overviews, this would provide

the DSB must adopt it within thirty days of its circulation to the Members. DSU art. 17-18.

135. See Shirley S. Abrahamson \& Robert L. Hughes, Shall We Dance? Steps for Legislators and Judges in Statutory Interpretation, 75 MinN. L. REv. 1045, 106170 (1991) (providing an overview of the range of mechanisms and institutions established at the state level to monitor judicial interpretations in the United States).

136. Examples include the Advisory Centre on WTO Law (ACWL) or the International Centre for Trade and Sustainable Development (ICTSD), or law firms such as Sidley Austin LLP. For a description of some of the workshops held by ICTSD in conjunction with the WTO and the ACWL, see http://www.ictsd.org/tags/legal-capacity.

137. Interview 4.1, in Geneva, Switz. (Jan. 16, 2014). 
less active Members with a critical resource to formulate their own interpretive preferences. There is no guarantee that representatives would review and act on the information contained within dispute report summaries, but its ready availability might incentivize governments to undertake such low-cost risk-averse behavior.

As noted previously, some Members use third party participation as a strategy for familiarizing themselves with WTO rules and jurisprudence and as a form of capacity building. ${ }^{138}$ One Member that has actively pursued this strategy claimed that its country now was "in a better position than twenty years ago when [they] needed someone from the outside to tell them that there was a problem ...." Through experience, he claimed, they had now "learned how to use the system." 139 More active DSB participation could potentially have the same type of capacity-building effect, particularly for developing countries. A number of developing country representatives suggested that it could do so because "participation helps you understand certain dynamics . . . . Attending the DSB meetings ... is like being a third party." "40 By engaging in meaningful report discussions, Members that do not currently attend or express views will improve their experience and thus capacity to participate actively within DSB meetings and potentially future dispute proceedings.

Stepping outside the text of the WTO Agreement and formal mechanisms of legislative response could be considered overreaching or meddling with the Organization's judicial bodies. Yet the DSU does provide Members with the right to express views, which some Members already use to voice their interpretive preferences. We are not arguing that report views should in any way bind future jurisprudence or that panels and the $A B$ should always follow the interpretive preferences of a majority of Members-after all the DSM was delegated independent authority to interpret and clarify the WTO agreements. However, their delegated role is to do so in ways that help WTO Members achieve the goals of the Organization in the context of resolving a specific dispute. Interpretive views provide necessary information to the DSM in its independent

138. Interview 3.4, supra note 103.

139. Interview 5.3, in Geneva, Switz. (Jan. 16, 2014).

140. Interview 4.8, supra note 131. 
development of jurisprudence, just as the ordinary meaning of text, the travaux preparatoires of Agreement provisions and other sources of law do.

\section{Conclusion}

Almost a decade ago, the Sutherland Report on the Future of the WTO suggested that the DSB could and should play a "more constructive role" by establishing a special group of experts to analyze and report on particular dispute findings. ${ }^{141}$ The Report further proposed that the DSB could adopt these expert reports or use them to recommend an Article IX:2 authoritative interpretation. While the Sutherland proposal had the potential of overcoming many of the challenges addressed in this Article, almost ten years later there have been no noticeable efforts to bring it to life.

Time has come for a renewed effort to address the growing institutional imbalance within the WTO and better enable the DSM to fulfill its fiduciary duties. To this end, this Article has sought to develop a proposal that should prove useful to both WTO Members and the DSM. Drawing on the strengths of previous proposals but addressing their current shortcomings, we encourage more Members to adopt an active and forward-looking practice of expressing views in the context of report adoption within DSB meetings. This proposal has a real chance of succeeding due to the fact that it is rooted in individual practices of Members, a large number of which desire to make the DSB more useful in terms of providing constructive feedback to the panels and Appellate Body. Given that the Organization is comprised of 162 Members, with different and often conflicting interests, the ability to reach the requisite consensus for an authoritative interpretation is limited. Our proposal has the potential to circumvent this decision-making requirement in a way that improves the interpretive feedback available to the DSM.

Most Members and WTO officials proudly view the WTO's dispute settlement system-and particularly the Dispute Settlement Body - as the most efficient of the WTO bodies. ${ }^{142}$ In a

141. Sutherland Report, supra note 24, I 250.

142. Interview 1.1, supra note 73; Interview 1.3, supra note 76; Interview 2.1, supra note 64; Interview 2.2, supra note 101; Interview 4.5, supra note 102. 
sense, however, the DSB has become a victim of its own success, resulting in an almost hyper-efficient body, wherein the ability to expedite disputes takes precedence over developing a broader understanding of interpretive developments within the WTO. By encouraging more Members to engage actively in dialogue with each other regarding jurisprudential developments, our proposal seeks to strengthen the deliberative role of the DSB without undermining its efficient administration of the DSU. In order to do so, Members need to move away from using report statements to simply reiterate legal positions pleaded during the dispute, and should instead proactively use such statements to engage in a cooperative endeavor with the DSM to strengthen WTO jurisprudence for the future. The DSM obviously does not have to decide future disputes based on views expressed-whether a minority or a majority-but it should, particularly in light of its fiduciary duties, be aware of these interpretive preferences and take them into account as one of the many factors relevant to interpreting the WTO agreements.

More critically, the interpretive views available to the DSM should reflect those of the membership as a whole. The hyperefficiency of the DSB has left a large number of Members that rarely use the system with little to no awareness or understanding of what goes on in the "black box" of the DSM. ${ }^{143}$ Similar to the way that third-party participation has become an important avenue for influencing the outcomes of disputes, ${ }^{144}$ we encourage Members that rarely participate in dispute settlement to reconsider the DSB as a useful platform that may have an "important effect on the thinking of the $A B$ members and the panelists for future cases." 145

It is important to reiterate that our proposal is not to encourage Members to overreach, meddle or interfere with the judicial bodies of the Organization. The DSM was delegated independent authority to interpret and clarify WTO rules, and views expressed in DSB meetings should not in any way be seen to bind panels or the AB. Any political interference or direct interaction with the panelists or Appellate Body members outside of dispute settlement proceedings would seriously

143. Interview 5.1, supra note 109.

144. See supra note 27 , at 474 and accompanying text.

145. Sutherland Report, supra note 24, II 250. 
undermine the credibility of the system. This does not mean, however, that indirect deliberative engagement cannot or should not occur via the official minutes of DSB meetings, with the sole expectation being that the Members and the DSM listen to one another. To this end, it is crucial that Members understand how more active DSB participation and expression of views in the context of report adoption might benefit them now and in the future. If Members see the value in changing their current practices, either individually or jointly, and perhaps with the institutional support of the Secretariat, this proposal has a real chance of succeeding. 
Imaged with Permission of N.Y.U. Journal of International Law and Politics 